\title{
Contact-Induced Change in Southern Bougainville
}

\author{
Bethwyn Evans and Bill Palmer \\ MAX PLANCK INSTITUTE FOR EVOLUTIONARY ANTHROPOLOGY, LEIPZIG, \\ AND UNIVERSITY OF NEWCASTLE
}

\begin{abstract}
The Northwest Solomonic Austronesian languages of Bougainville and the western Solomon Islands display numerous linguistic characteristics that are atypical of other Austronesian languages of the Oceanic subgroup. These innovative features have been assumed to reflect linguistic contact with the Papuan languages of the region. However, while contact-induced change resulting from social contact between speakers of Austronesian and Papuan languages has been shown to play a significant role in the history of a number of languages and groups of languages in Melanesia, there has been little detailed research on the Northwest Solomonic subgroup.

The Mono-Uruavan languages (Mono, Uruava, and Torau), a subgroup within Northwest Solomonic, are particularly aberrant with regard to grammatical structures. They display right-headed structures including SOV clauses, postpositions, and preposed possessors. We argue that these innovative structures arose through Mono-Uruavan speakers' social contact with speakers of neighboring Papuan languages of the South Bougainville family (Nasioi, Nagovisi, Buin, Motuna).
\end{abstract}

\section{INTRODUCTION}

\section{1 “ABERRANT" AUSTRONESIAN LANGUAGES OF MELANESIA.}

The Austronesian languages of the Melanesian region have long been viewed as different from those of Micronesia and Polynesia in ways that raise questions regarding their historical development. Grace $(1981,1992,1996)$ describes this difference as a continuum from more "aberrant" to more "exemplary" languages, noting the presence of many more aberrant Austronesian languages in Melanesia than in the other two regions of Oceania. By aberrant, Grace $(1992,1996)$ means a language with which the application of the Comparative Method of historical linguistics yields results that are complex and difficult to interpret. (For discussion of the comparative method see Rankin 2003 and Harrison 2003.) Grace lists four ways in which languages can be aberrant: (i) they show relatively few cognates with other Austronesian languages; (ii) they are structurally atypical of the Austronesian languages of their subgroup (for example, Oceanic); (iii) they have large phoneme inventories and phonetic features that are atypical of Austronesian languages; and/or (iv) they do not show unambiguous regular sound correspon- 
dences, but rather often display multiple sets of contrasting correspondences. Languages with one or more of these features raise the question of what kinds of historical explanations account for their atypical nature. There is continuing debate regarding the histories of these "aberrant" languages in Melanesia (see Pawley 2006). ${ }^{1}$

Ross (1988) demonstrated that the application of the Comparative Method to the Austronesian languages of northwestern Melanesia, namely Papua New Guinea and the northwestern Solomon Islands, does in fact yield regular sound correspondences and patterns of shared innovations that indicate phylogenetic relationships among the languages of the region. However, Ross (1988) also notes that these languages are characterized by a high degree of linguistic diversity or, in Grace's (1981) terms, are aberrant with respect to features (i) and (ii). For example, in terms of lexicon, languages of the Northwest Solomonic (henceforth NWS) subgroup are among the most innovative within the Austronesian family. That is, these languages retain proportionally fewer Austronesian etyma than other languages in the family (see Blust 2000, Pawley 2009, Ross 2010). Also, certain languages within this subgroup, in particular the Mono-Uruavan ones, show highly atypical grammatical structures in comparison with other Austronesian languages of the region.

There is agreement in the literature that in this northwest region of Melanesia the linguistic diversity reflects histories of contact-induced change, resulting from widespread bilingualism among speakers of Austronesian and Papuan languages (Lynch 1981, Ross 1988, Pawley 2006). Thurston $(1982,1987,1994)$ and Ross $(1996,2008)$ investigate the atypical or aberrant grammatical structures in Austronesian Lusi (West New Britain, Papua New Guinea) and Takia (Karkar island, Papua New Guinea), respectively. They show that these structures are similar to ones found in neighboring Papuan languages, and that they reflect contact-induced change. Comparable aberrant structures in other Austronesian languages of northwestern Melanesia, including the three Mono-Uruavan languages of the southern Bougainville region, have been presumed to reflect similar processes of contact-induced change.

\subsection{LANGUAGES OF THE SOUTHERN BOUGAINVILLE REGION.}

All of the Austronesian languages of Melanesia east of about $138^{\circ}$ East are part of the large Oceanic branch of the family (see Lynch, Ross, and Crowley 2002). The Oceanic

1. We are very grateful to all the people in Bougainville and the Solomon Islands who assisted us in our fieldwork, in particular those of Rorovana, Bougainville (Palmer and Evans), Takoo', Bougainville (Evans), Goveo, Santa Isabel (Palmer), and Marovo Lagoon, New Georgia (Evans). Evans gratefully acknowledges a Simon Research Fellowship (University of Manchester, 2004-2008); a British Academy Small Grant (SG40401; 2005-2006), supporting fieldwork on Marovo; and the Max Planck Society, which provided financial support for Evans's fieldwork in Bougainville and for research on which the paper is based. Palmer gratefully acknowledges UK Arts and Humanities Research Council Research Grant APN19365 (2005-2008), supporting fieldwork in Bougainville; and British Academy Small Research Grant SG44063 (2006-2007), which funded preparation of Palmer's Torau materials. We would like to thank Claudia Jorek and Claire Turner for assistance with Torau data entry. Earlier versions of the paper were presented in 2010 at the Workshop on the Languages of Papua 2 (Manokwari, Indonesia), the Australian Linguistics Society Conference (Brisbane) and the Linguistics Department at the Max Planck Institute for Evolutionary Anthropology (Leipzig), and in 2011 at the International Congress on Historical Linguistics (Osaka). We would like to thank audiences for their comments. We also thank Brigitte Pakendorf, Ger Reesink, Malcolm Ross, and two anonymous reviewers for their comments on an earlier draft of the paper. 
languages of Bougainville, Buka, and Nissan islands in Papua New Guinea, and of the Shortland Islands, Choiseul, Santa Isabel, ${ }^{2}$ and New Georgia in the Solomon Islands form the NWS subgroup within Oceanic (Ross 1988).

Within NWS, it is the Mono-Uruavan subgroup (Ross 1988) comprising three languages - Mono, Uruava, and Torau — that display highly atypical grammatical structures. Mono is spoken on the Shortland Islands in the Solomon Islands, off the southern coast of Bougainville; Uruava, now extinct, was spoken in the coastal region of Bougainville near what is now Arawa town; while Torau is spoken in four villages along the coast to the north of Arawa. Although Torau speakers are now geographically separate from Mono speakers, oral histories, early ethnographic records, and archaeological research indicate that their ancestors migrated from the southern coast of Bougainville, and probably originally from the Shortland Islands, in the mid-nineteenth century (Laracy 1969, Terrell and Irwin 1972). Contemporary locations of other NWS languages are somewhat distant from Mono and Torau. In Bougainville, other NWS languages are spoken on the west coast in this southern area (Piva and Banoni), further north on the east coast (Papapana), and on the northern tip of the island (for example, Teop, Tinputz, Hahon), as well as on the island of Buka to the north and its smaller offshore islands (for example, Halia, Solos, Petats). To the southeast, NWS languages are spoken on Choiseul Island (for example, Ririo, Vaghu, Babatana), in the New Georgia group of islands (for example, Kubokota, Roviana, Hoava, Marovo), and on Santa Isabel (for example, Zabana, Kokota, Cheke Holo).

The closest contemporary neighbors of Mono-Uruavan speakers are speakers of two non-Austronesian or Papuan languages: Buin (in the case of Mono), and Nasioi (in the case of Torau and, until it became extinct in the mid-twentieth century, Uruava). These two Papuan languages appear to be closely related to each other, and to their neighboring languages Motuna and Nagovisi. All four languages form the South Bougainville language family, and are phylogenetically distinct from other Papuan languages of the region (Ross 2005, Evans 2009). ${ }^{3}$ South Bougainville languages are spoken across the southern third of Bougainville. Nasioi is spoken in the northeastern part of the South Bougainville region in both coastal and inland areas, while Nagovisi is an inland language in the northwest of the region. Motuna and Buin are spoken towards the south of Bougainville, Motuna to the southwest, and Buin across the southern tip of the island. Map 1 shows the distribution of Oceanic and Papuan languages in Bougainville and the northwestern Solomon Islands and the location of the languages discussed in the paper.

Evidence that there was social contact and interaction among the different ethnolinguistic groups of southern Bougainville historically can be seen in the genetic, archaeological, and early ethnographic research. For example, genetic studies of the island region of northwestern Melanesia in general indicate that there has been considerable intermixture of different ethnolinguistic populations, particularly within islands and in the coastal areas (see Scheinfeldt et

2. With the exception of Bugotu at the southeastern tip of Santa Isabel, which belongs to the Southeast Solomonic subgroup.

3. Large-scale typological studies of the languages of the island region of northwestern Melanesia suggest deep-time historical relationships among all the Papuan languages (Dunn et al. 2008; Dunn 2009). However, it is not clear if these reflect phylogenetic relationships or ancient linguistic contact. As wider phylogenetic links across the region remain unproven, for the present paper we treat the South Bougainville languages as genetically distinct from other Papuan languages of northwestern Melanesia. 


\section{MAP 1. LOCATIONS OF OCEANIC AND PAPUAN LANGUAGES DISCUSSED IN THE PAPER}

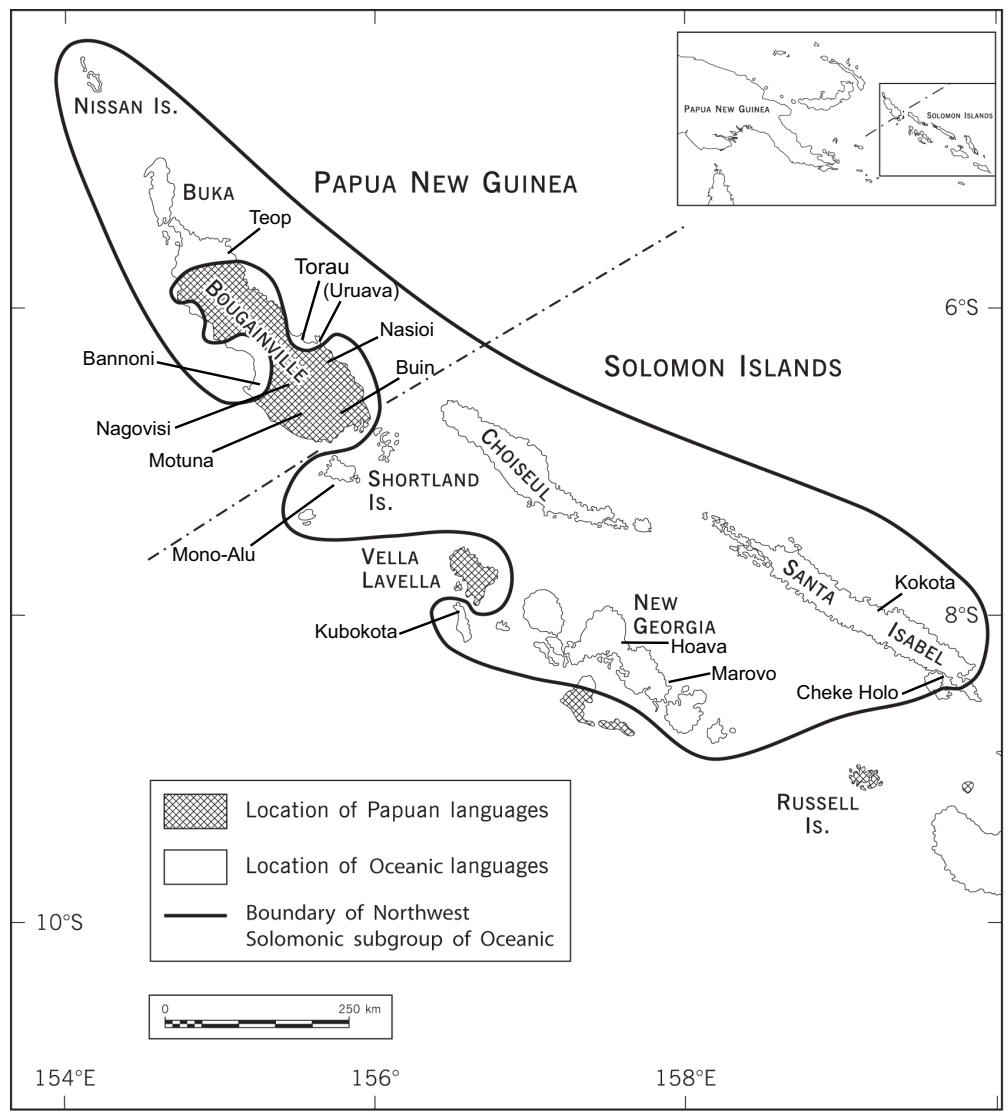

al. 2007, Friedlaender et al. 2007, Friedlaender et al. 2008, Hunley et al. 2008). Archaeological sites on the east coast in what are now Torau and Nasioi speaking areas, in the southwest Buin speaking area, and in the Shortland Islands all show similar sequences of different pottery styles, dating from around $\mathrm{AD} 400$, that are interpreted as reflecting cultural contact among these different areas. In fact, it is suggested that pottery making and designs were introduced to the Buin region from the Shortland Islands (Irwin 1973, Spriggs 1992). Ethnographic research points to similar patterns of social and cultural interaction, with records of more trade and marriages occurring across ethnolinguistic boundaries in coastal areas than in inland areas (Ogan 2005). Also, the cline seen in Nagovisi, Motuna, and Buin speaking groups on Bougainville Island from strong to weak matrilineal descent, as well as weak to strong social stratification, and cultural value of pigs and shell money, are viewed as reflecting a cline from less to more social contact with Shortland Islanders (Keil 2005). ${ }_{4}^{4}$ Oral histories recorded from the late nineteenth century onwards describe a migration of Torau people to 
their current location on the east coast north of Arawa from an area of the Buin speaking region on the southwest coast, and perhaps originally from the Shortland Islands, which is explained as resulting from social conflicts among neighboring groups of people (see Laracy 1969, Terrell and Irwin 1972). Synchronically, there is regular social interaction among people from different ethnolinguistic groups in southern Bougainville and the Shortland Islands, particularly at markets in Arawa and Buin. However, today the language of intergroup communication is typically Tok Pisin, the English-based creole that is a national language of Papua New Guinea.

1.3 DETERMINING CONTACT-INDUCED CHANGE. In this paper, we examine three areas of grammatical structure: clause order; the expression of oblique arguments and adjuncts; and possessive constructions. We argue that these structures in the Mono-Uruavan languages reflect contact-induced change under the influence of the neighboring South Bougainville languages. In support of this analysis we provide two types of evidence.

First, we demonstrate that the constructions in the Mono-Uruavan languages are indeed innovative. This is done through comparison of the Mono-Uruavan constructions with those in other NWS languages, highlighting the kinds of constructions that are typical of NWS languages, and illustrating the ways in which the Mono-Uruavan languages are different. Structures are taken to be typical of NWS languages if they are present in several of the first-order groupings within the subgroup, which, in addition to Mono-Uruavan, include North Bougainville, Banoni-Piva, Choiseul, New Georgia, and Santa Isabel (see Ross 1988, 2010). Support for the innovative nature of the Mono-Uruavan languages is also based on the typology of Oceanic languages more generally, as well as reconstructions of both Proto-NWS and Proto-Oceanic (see Ross 1988, Lynch, Ross, and Crowley 2002).

Second, we test the hypothesis that these innovative structures in Mono-Uruavan may result from contact-induced change through comparison with structures in the neighboring Papuan languages of the South Bougainville family. Little reconstructive work has been carried out on South Bougainville, but constructions that are similar across the four languages are taken to be typical of the family as a whole, and thus likely to have been present in earlier stages of the languages' history.

Difference in structures between Mono-Uruavan languages and other NWS languages, and resemblance between Mono-Uruavan and the South Bougainville languages are taken as evidence that the innovative structures in Mono-Uruavan do indeed reflect contact-induced change resulting from social contact among speakers of Mono-Uruavan languages and their South Bougainville speaking neighbors. Some indications of the relative chronology of certain changes and patterns of resemblant structures across particular Mono-Uruavan and South Bougainville languages will also be mentioned.

2. "ABERRANT" STRUCTURES IN MONO-URUAVAN. The three MonoUruavan languages - Mono, Torau, and Uruava - show a number of syntactic characteristics that are not only atypical of Oceanic languages in general, but are also different from

4. As noted by one reviewer, these apparent cultural changes in Motuna and Buin speaking groups are most likely not independent of each other. That is, the increasing cultural value of pigs and shell money was likely connected to the shift towards more stratified social organization. 
other NWS languages. Most strikingly, these languages have SOV basic clause order, suggesting a right-headed VP, as well as the expected correlations of postpositions and possessor + possessum (PSSR + PSSM) order in possessive constructions (see Dryer 2007). Each of these structural features resembles those found in the neighboring Papuan languages. In this section we compare (i) clause order, (ii) the expression of obliques, and (iii) possessive constructions in NWS languages generally, Mono-Uruavan languages in particular, and South Bougainville languages generally, highlighting the innovative features in Mono-Uruavan languages that resemble structures in the neighboring South Bougainville languages.

\subsection{CLAUSE ORDER}

2.1.1 Clause order in NWS. In most NWS languages, the pragmatically unmarked clause order is verb-initial, as demonstrated by (1a) from Kokota (Santa Isabel subgroup) and (2a) from Marovo (New Georgia subgroup). ${ }^{5}$ In both Kokota and Marovo, a noun phrase denoting a topicalized referent with any grammatical relation may occur preverbally, as in (1b) from Kokota and (2b) from Marovo, where the object noun phrase occurs sentence-initially. ${ }^{6}$

(1) KOKOTA (SANTA ISABEL, NWS, OCEANIC)
a. N-o fa-lehe=ri ago kokorako are. $^{7}$
RL-2.SBJ CAUS-die=3PL.OBJ 2SG chicken those.PROX ${ }^{8}$
'You are killing those chickens.'
(Palmer 2009b:279)
b. Are-lau tahe $=$ di ago.
those.PROX-SPC tell=3PL.OBJ yousG
'Those ones (parts of a story just mentioned) you will tell.'

(Palmer 2009b:286)

(2) MAROVO (NEW GEORGIA, NWS, OCEANIC)
a. Loa tera ni-a hami Eva pa vasina. ${ }^{9}$ leave away TR-3SG.OBJ 1EXCLPL E. LOC place
'We left Eva there.'

(Evans fieldnotes)

5. "Verb" in this discussion of clause order refers not simply to the verb stem itself, but to what is typically referred to in the Oceanic literature as the "verb complex." No attempt has been made to model the syntactic status of the verb complex. However, the term is typically (and most meaningfully) used to refer to the verb (or sequence of verbs in a serial construction) with its accompanying markers of tense, aspect, and mood, along with transitivity and participant reference, but excluding arguments. The exclusion of the object NP from the verb complex means it does not equate to a Verb Phrase. The verb complex is highlighted throughout this section.

6. See Palmer (2009a) for a detailed discussion of the pragmatic contexts of preverbal arguments in the Santa Isabel language Cheke Holo.

7. Symbols in the Kokota orthography present in the data have their expected IPA values except that $g=/ \mathrm{\gamma} /, \bar{g}=/ \mathrm{g} /$, and $m h=/ \mathrm{m} /$.

8. Abbreviations in all examples have been modified to follow the Leipzig Glossing Rules. In addition, the following abbreviations are used: CNSPOSS, "consumed" possession; DEP, dependent verb marker; DES, desiderative; DIM, diminutive; GENPOSS, general (i.e., default) possession; HAB, habitual; IMM, immediate change of event; IMMPST, immediate past; LINK, linker; MIDPST, mid past; NRPST, near past; PART, participle; PCL, paucal; PRT, particle; PSSM, possessum; PSSR, possessor; RD, reduplicant; RL, realis; RMPST, remote past; SS, same subject; VOL, volitional.

9. Symbols in the Marovo orthography present in the data have their expected IPA values except $g h=/ \gamma /, v=/ \beta /$, and $n g=/ \mathrm{y} /$. 
b. Ria karua hae moko vae gone-i hami.
ART.PL two tree usually take usually-TR 1EXCLP

'Only those two trees (just mentioned), we usually use.'

(Evans fieldnotes)

These same two clause orders occur in Banoni (Banoni-Piva subgroup), illustrated by comparison of (3a), where the Topic referent is denoted by the clause-initial pronoun, and (3b), where nna 'he' is no longer the Topic, and so occurs postverbally. Lynch and Ross (2002:451) thus describe the basic clause order of Banoni as comprising an optional initial Topic followed by the verb. Teop (North Bougainville subgroup), on the other hand, requires a clause-initial Topic, meaning that the verb of a clause always occurs in second position. This is illustrated in (4a), where the preverbal Topic is the subject, and in (4b), where it is the object. The frequent association of Topic with subject means that the most commonly occurring clause order in Teop is SVO, where $\mathrm{S}$ is actually in Topic position (Mosel and Thiesen 2007:§5, p.1). Ross (2002:463ff.) presents a similar analysis of Sisiqa (Choiseul subgroup): that is, a verb-second language with a clause-initial Topic position.

(3) BANONI (BANONI-PIVA, NWS, OCEANIC)

$\begin{array}{llll}\text { a. Nna ke } & \text { tsun-a } & \text { ma=i } & \text { borogho, }{ }^{10} \\ \text { 3SG } & \text { 3SG.SBJ.RL } & \text { kill-3SG.OBJ } & \text { hither=ART } \\ \text { pig }\end{array}$

'He killed a pig,

(Lynch and Ross 2002:451)

b. ke ne sune-a nna.

3SG.SBJ.RL then singe-3SG.OBJ 3SG

and then singed it.'

(Lynch and Ross 2002:451)

(4) TEOP (NORTH BOUGAINVILLE, NWS, OCEANIC)

a. A moon vai kahi vahio ni nana bona otei. ${ }^{11}$

ART woman DEM IRR marry APPL IPFV.3SG.SBJ ART man

'This woman will marry the man.' (Mosel and Thiesen 2007:§5, p.1)

$\begin{array}{llllll}\text { b. O pipi vai na dao ri-ori } & \text { bono toka-pis. } \\ \text { ART } & \text { sore DEM RL call IPFV.3PL.SBJ-3PL ART t.-p. }\end{array}$

'These sores, they call toka-pis.' (Mosel and Thiesen 2007:§9.5, p.1)

In summary, in all but one of the first-order NWS subgroups (Santa Isabel, New Georgia, Choiseul, Banoni-Piva, and North Bougainville) the basic clause order is Topic, followed by the verb, followed by pragmatically unmarked arguments. The apparent order of postverbal $\mathrm{S}$ and $\mathrm{O}$ varies from subgroup to subgroup: some languages, such as Kokota and Marovo, have an apparent VSO order; others, such as Sisiqa (Ross 2002), are VOS. Still others, such as Teop, require the Topic position to be filled. Crucially for the present study, all are verb-initial, in the sense that the verb precedes any pragmatically unmarked arguments, with a preverbal argument position conforming to strict information structure restrictions (see Palmer 2009a). This order is expressed by Ross (1988) as TVX, where X refers to any nontopic argument.

$\overline{10 .}$ Symbols in the Banoni orthography present in the data have their expected IPA values except $g h=/ \mathrm{y} /$ and $t s=/ \mathrm{t} /$.

11. Symbols in the Teop orthography present in the data have their expected IPA values except $v=$ $/ \beta /$ and $a o=/ 0 /$. 
2.1.2 Clause order in Mono-Uruavan. The one NWS subgroup where the TVX generalization does not hold is Mono-Uruavan, which instead displays SOV basic clause order. In the limited Uruava data (Rausch 1912, Oliver 1938-39), the verb follows all core arguments in all clauses, as, for example, in (5).

(5) URUAVA (MONO-URUAVAN, NWS, OCEANIC)
a. aria kasiko podo-i. ${ }^{12}$
1SG stone.axe have-3SG.OBJ
'I have a stone axe.'
b. raro udaka $=$ ia k-o $\quad$ ßa-pius-i.
pot fire $=$ LOC IRR-2SG.SBJ CAUS-sit-3SG.OBJ
'Put the pot on the fire.'

(Rausch 1912:981)

(Rausch 1912:981)

In pragmatically neutral clauses in Torau, the verb also occurs following all core arguments, as illustrated by (6a). However, it is possible for the object noun phrase to occur postverbally when the focus of the clause is the event. This is shown in (6b). ${ }^{13}$

(6) TORAU (MONO-URUAVAN, NWS, OCEANIC)
a. Inau boo ma-gu atun-a. ${ }^{14}$
1SG pig RL-1SG.SBJ smite-3SG.OBJ
'I killed a pig.'
b. Inau a ana e-gu=to iala.
1SG IPFV eat SBJ-1SG.SBJ=PRS fish
'I am eating the fish'

(Palmer fieldnotes)

(Palmer fieldnotes)

In Mono, the clause order appears to be much more variable. However, Fagan (1986:84) does describe verb-final clause order, a distinctive structure of Mono-Uruavan within NWS, as the "unmarked" order in both intransitive and transitive clauses. In intransitive clauses, both SV and VS orders occur with equal frequency, but Fagan (1986:84) describes SV as the unmarked structure, since postverbal subjects in intransitive clauses are usually formally marked by the preposition $g a$, which Fagan (1986) describes as an absolutive case marker, whereas preverbal subjects are formally unmarked; compare examples (7a) and (7b). Example (7b) also illustrates that it is possible for an adpositional phrase to follow the verb complex in Mono, also attested in Torau. In transitive clauses, all possible orders of S, O, and V are attested. However, SVO and SOV clauses appear to occur most frequently (Fagan 1986:84), and again, Fagan (1986:84) describes SOV order as the unmarked one, since an object noun phrase that precedes the verb is formally unmarked, whereas an object noun phrase following the verb typically occurs with the preposition $g a$. This is illustrated by examples (7c) and (7d) ${ }^{15}$

12. Uruava data are presented in IPA.

13. There are also pragmatic differences between clauses with SOV and OSV order in Torau, but these will not concern us in the present paper.

14. Symbols in the Torau orthography present in the data have their expected IPA values.

15. Fagan's (1986) description of Mono is based on a corpus of some 70 texts collected in 1908-1909, published as Wheeler (1926). Examples cited as Fagan are originally from Wheeler. However, as Wheeler's texts are not glossed, and the free translations for each entire text is located separate to the text itself, we have chosen as examples data used by Fagan, and Fagan is cited as the source rather than Wheeler, so that the interested reader can check our analysis using readily interpretable data. 
(7) MONO (MONO-URUAVAN, NWS, OCEANIC)

a. Ea Sakusaku i-lefe. ${ }^{16}$

ART S. 3SG.SBJ.RL-leave

'Sakusaku went away.'

(Fagan 1986:92)

b. Iri-lefe ma famata $=\operatorname{ng}^{17}$ ga aanana.

3PL.SBJ.RL-return hither village $=$ LOC ABS children

'The children went back to the village.'

c. Maang boo lafulu emia-gagana emia-galo-ri ma.

'You go and bring back ten pigs.'

(Fagan 1986:103)

d. Ea magota bau ena-lapu-ri ga sa-gu talaiva.

ART old.woman NEG 3SG.SBJ.IRR-kill-3PL.OBJ ABS GENPOSS-1SG.PSSR women.

'The old woman shall not kill my wives.'(Fagan 1986:101)

2.1.3 Clause order in South Bougainville. Like Mono-Uruavan languages, the Papuan South Bougainville languages are also characterized by SOV clause order. In Motuna, the best described of the four South Bougainville languages, it appears that all possible orders of the subject, object, and verb are possible, although SOV order appears to be the most frequent and the least marked pragmatically (see Onishi 1994:60ff.). Onishi (1994) describes the order of intransitive clauses as SV, illustrated in (8).

(8) MOTUNA (SOUTH BOUGAINVILLE, PAPUAN)

... tii pehka po'tee meeng ooruh-u-u-na. ${ }^{18}$

ART.F young.girl very very become.afraid-3.SBJ-RMPST-F

'... the young girl became very afraid.'

(Onishi 1994:62)

In transitive clauses, the preverbal order of the subject and object depends on both topicality and case marking. That is, if the referent of the transitive subject is the Topic of the sentence, then it must be unmarked for case and precede the object, as shown in (9a). Otherwise, the transitive subject takes ergative case marking and clause order is free. Thus in (9b) the ergative-marked subject follows the object.

(9) MOTUNA (SOUTH BOUGAINVILLE, PAPUAN)
a. Hoo Paanaangah tii Perui tu-u-ng.
ART.M P. ART.F P. kill-3.OBJ:3.SBJ.RMPST-M
'Paanaangah (Topic) killed Perui.'
(Onishi 1994:60)
b. ... tii Perui ho-i Paanaangah tu-u-na.
ART.F P. ART.M-ERG P. kill-3.OBJ:3.SBJ.REMPAST-F
‘... Perui (Topic) was killed by Paanaangah.' ${ }^{19} \quad$ (Onishi 1994:60)

\footnotetext{
16. Symbols in the Mono orthography present in the data have their expected IPA values except $n g=/ \mathrm{y} /$. It is not known whether $f$ and $v$ refer to labiodental or bilabial fricatives.

17. The form and clitic nature of the Mono postposition has been modified from the original throughout. See the second footnote to table 2 below.

18. Symbols in the Motuna orthography present in the data have their expected IPA values except $n g=/ \mathrm{y} /$ and the apostrophe $=/ \mathrm{P} /$.

19. Although Onishi (1994) translates this clause with an English passive, it is not a grammatically passive construction in Motuna. A more accurate translation may be 'Perui Paanaangah killed'.
} 
Not all clauses in Motuna are verb-final. A subject or object that expresses "new" information may occur following the verb (Onishi 1994:4), as in example (10), suggesting a postverbal Focus position. ${ }^{20}$

(10) MOTUNA (SOUTH BOUGAINVILLE, PAPUAN)

Tiwongori ong motukah a-matu motuk-e-u-r-u-ng

therefore DEM.M island DEM-CLF.patch spare-APPL-3.OBJ:3.SBJ-PCL-RMPST-M

so-i Maawo.

ART.M-ERG M.

'Therefore Maawo spared this patch of island for them.' (Onishi 1994:545)

In Buin, the verb strictly follows all core arguments, as the examples in (11) show. Laycock (n.d.:6) describes the order of core argument noun phrases as determined not by their grammatical relations, but by their relative position on an animacy hierarchy, with arguments higher on the hierarchy occurring before arguments lower in animacy. ${ }^{21}$ Thus the clause order in (11a) is OSV because the object is expressed by a 1st person pronoun and the subject by a 2 nd person pronoun, whereas in (11b) the order is SOV, as the inanimate object follows the animate subject. However, if the referents of two arguments are equal in animacy, the clause order is SOV (Laycock n.d.:6). Not all the examples in Laycock (2003) support this analysis. For example, in (11c) the clause order is SOV even though the object denotes a human referent and the subject a nonhuman animate. It appears, therefore, that SOV is the preferred clause order in Buin.

(11) BUIN (SOUTH BOUGAINVILLE, PAPUAN)
a. Ne ro mina-m-e-i. ${ }^{22}$
1SG 2SG hide-1.OBJ-2.SBJ-IMMPST
'You hide me.'23

(Laycock n.d.:6)

20. Onishi (1994) follows Chafe's (1976) definition of the distinction between "given" and "new." A "new" referent is one that the speaker assumes is not in the "consciousness of the addressee at the time of the utterance" (Chafe 1976:30). However, the texts that Onishi (1994) presents indicate that the new/given contrast may not account adequately for all examples of postverbal noun phrases in Motuna. It appears that Motuna clause-final Focus position may be the locus of participants with a range of focal functions, not merely new information, as Palmer (2009a) argues for the NWS language Cheke Holo. However, further research on Motuna information structure is needed in order to propose a more fine-grained analysis of clause order variation in that language.

21. Laycock (n.d.:6) gives the hierarchy as: 1 st pronoun $>2$ nd pronoun $>3$ rd pronoun $>$ human noun $>$ animate noun $>$ inanimate noun, following (without citing) Silverstein (1976), but describes it as a hierarchy of topicality rather than animacy.

22. Buin examples and analysis are from three sources: Laycock (n.d.); Griffin (1974), and Laycock (2003). Detailed morpheme-by-morpheme glosses of examples are not provided in any of these sources. We have added glosses to the Buin examples cited here based on grammatical analyses given in all three sources and the extensive lexical information presented in Laycock's (2003) dictionary. All data are presented in the orthography used by Laycock (2003). All symbols have their expected IPA value.

23. Laycock (n.d.:6) gives the verb forms in this clause as mina-m-ei. However, from the verbal paradigms given in Laycock (2003:xix-xx), it appears that $-e$ denotes a 2 nd person subject and $-i$ immediate past tense. Immediate past verb forms are used to denote immediate past tense and future tense (along with a preverbal particle), while present tense verb forms are used to indicate present continuous actions (Laycock 2003:xvi). From the translations provided for clauses with immediate past verb forms in Laycock (n.d.) and Laycock (2003), it appears that Buin immediate past tense is used in contexts where the simple present is used in English. 
b. Urugito toku oo-k-u-i.

pig fence break-3.OBJ-3.SBJ-IMMPST

'The pig breaks the fence.'

(Laycock 2003:129)

c. Ako-i maikuna roi-kene kaku-t-u-n-guo.

DEM-ERG dog man-PL bite-3.OBJ-3.SBJ-PL-HAB

'This dog bites people.'

(Laycock 2003:37)

In Nagovisi, verb-final clause order also appears to be obligatory, as illustrated in (12). However, the data presented by Decker (1981) are limited and further research may reveal variant clause orders.

(12) NAGOVISI (SOUTH BOUGAINVILLE, PAPUAN)

a. Tewöö maniku' ke'maki' kasi'-nöö we-ro-iee' ${ }^{24}$

3PL women yesterday garden-LOC 3/2.go-PL-MIDPST

'The women went to the garden yesterday.' (Decker 1981:61)

b. Ero nggo-ke Iööni' kokoree' a-w-u-i.

today 1SG.PSSR.mother-ERG J. chicken give-3SG.OBJ-1SG.SBJ-NRPST

'My mother gave John a chicken today.'

(Decker 1981:59)

The basic clause order in Nasioi is also verb-final, and there is a tendency for the subject to precede the object, as in (13a). However, as in Motuna, in Nasioi this is not the only attested order, and it is possible for a noun phrase to follow the verb, as illustrated in (13b). The pragmatic functions of different clause orders and of postverbal NPs in Nasioi are not yet fully understood, and further research is needed.

(13) NASIOI (SOUTH BOUGAINVILLE, PAPUAN)
a. Ning-e aung kapoo meu'-p-ans-ing. ${ }^{25}$
1SG-ERG DEM thing find-3.OBJ-1.SBJ-IMMPST
'I found this thing.'
(Evans fieldnotes)
b. ... deto $\sim$ deto nanu-anta-u-ainge ba-kan-a
... uphill $\sim$ RD
go-CAUS-3.SBJ-FUT
'... he moves his garden uphill.'
(Evans fieldnotes)

In summary, the basic clause order in South Bougainville languages is SOV, with a possible postverbal argument in several of the languages. In NWS languages of subgroups other than Mono-Uruavan, the pragmatically unmarked clause order is verb-initial, with a single preverbal position for pragmatically marked arguments, typically a Topic. MonoUruavan languages in this respect resemble their South Bougainville neighbors, rather than other NWS languages. The basic clause order is SOV, with pragmatically marked postverbal arguments possible.

2.2 EXPRESSION OF OBLIQUES. While Oceanic languages typically encode oblique arguments and adjuncts with prepositions, Mono-Uruavan languages have a mixture of prepositions and postpositions. Postpositions are also characteristic of South Bougainville languages, as expected from their $\mathrm{OV}$ order.

24. Nagovisi examples follow the orthography in Decker (1981). All symbols have their expected IPA values except $n g=/ \mathrm{y} /$ and the apostrophe $=/ \mathrm{l} /$. The phonetic realization of $\ddot{o}$ is unclear.

25. Nasioi examples follow the orthography used by Hurd and Hurd (1970) and Hurd (1977), except $n g=/ \mathrm{y} /$ and the apostrophe $=/ 2 /$. All other symbols have their expected IPA values. 
2.2.1 Obliques in NWS. Typically, obliques in NWS languages are expressed as prepositional phrases, as illustrated in (14) from Hoava, where the verb complex is followed by two prepositional phrases: $p a h<i n>$ igala 'to the garden' and ta-ni sa 'with her'. Postpositions do not appear to occur in NWS languages outside Mono-Uruavan. ${ }^{26}$

(14) HOAVA (NEW GEORGIA, NWS, OCEANIC)

Toka sagele la pa $\mathbf{h}<$ in>igala ta-ni sa se Amina. travel go.up go LOC garden<NMLZ> COM-3SG 3SG ART A.

'Amina went up to the garden with her.'

(Davis 2003:223)

Table 1 presents an overview of prepositions and the semantic roles of the introduced participant in several NWS languages. ${ }^{27}$ Like many other Oceanic languages (Lynch, Ross, and Crowley 2002:51), NWS languages tend to have only a small number of different prepositions, one or two of which introduce participants with a wide range of semantic roles. For example, Kokota has a single true preposition $k a$ (Palmer 2009b:123ff), while Teop (North Bougainville) and Cheke Holo (Santa Isabel) have about six prepositional forms.

Not all of the prepositional forms in each of these languages exhibit the same morphological and syntactic behavior. Thus in Hoava (New Georgia), both the prepositions $p a$ and $t a$ - introduce participants with a wide range of semantic roles, differing in their occurrence with noun phrases denoting nonhuman versus human referents, respectively. ${ }^{28}$ However, while $p a$ can be described as a "true" preposition, $t a$ - could be described as a "nominal" preposition or relational noun, occurring as it does with person-number suffixes very similar to those that indicate possession with nouns; compare the use of $p a$ and $t a$ - in example (14).$^{29}$ In Banoni, on the other hand, the comitative preposition $m e-\sim$ $m a$ - occurs with person-number suffixes that resemble those that index the object on verbs. ${ }^{30}$ This distinction between "true" prepositions and noun-like or verb-like prepositions is found in many Oceanic languages (see Pawley 1973, Durie 1988). However, crucially for the present study, all of the forms in table 1 are prepositional - that is they

26. There are contexts in most Northwest Solomonic languages where an oblique occurs as a bare NP without any adpositional element or case-marking, often including place names and local nouns (see Ross 2003a). Such unmarked obliques are not relevant to the current paper and so will not be discussed here.

27. Semantic roles discussed in the text are given with their case abbreviation. A blank cell in this table indicates that we do not have information regarding the use of prepositions for that particular semantic role. In some instances, such as the instrumental in Hoava, we know that other constructions are used (for example, applicatives, serial verb constructions), and the same may also be true for other languages.

28. Hoava $t a$-also sometimes introduces noun phrases denoting nonhuman referents, but only if the noun phrase is pronominal or marked for definiteness by the definite article (Davis 2003:219).

29. The person-number suffixes that occur with prepositions are slightly different from those that occur in possessive constructions. With $t a-, 3 \mathrm{SG}$ is marked by $-n i$, rather than -na, the $2 \mathrm{SG}$ form $-m u$ is also used with 2PL referents, the 1PL EXCL form appears to have been reduced to - $m i$ from -mami, and the 1PL INCL form is - $d i$ (identical to 3PL) rather than - $d a$. For other personnumber categories, the suffixes that occur with $t a$ - are identical in form to the nominal possessor-indexing suffixes (see Davis 2003:97ff., 219).

30. The person-number suffixes that occur with $m e-\sim m a$ - differ from verbal object suffixes in that the 1SG form is $-a$ rather than $-a a$ and the 2 SG and 1PL inclusive forms lack the initial $i$ of the object markers-for example, 2SG - gho rather than -igho (see Lincoln 1976a:§7.7, Lynch and Ross 2002). 
precede the noun phrase denoting the introduced participant. ${ }^{31}$ This is illustrated in (15) from Kokota.

(15) KOKOTA (SANTA ISABEL, NWS, OCEANIC)

Suli=ana n-e faroh-i mheke=na ka=nihau gazu?

child=that.PROX RL-3.SBJ smite-TR dog=that.PROX LOC=how.many wood

'That child hit that dog with how many sticks?' (Palmer 2009b:124)

Another characteristic of NWS languages is that one or two prepositions tend to introduce participants with a wide range of semantic roles. Thus, although six prepositional forms are listed for Teop in table 1, te and ki are used with a wide range of semantic roles, while the other forms are more restricted in their use. Of relevance to the topic of this paper is the tendency for obliques expressing location, goal, and source to be marked by the same preposition (see table 1). The examples in (16) demonstrate that pa in Hoava is used to indicate static location (that is, locative) (16a), the goal of motion (allative) (16b), and the source of motion (ablative) (16c). In NWS languages, the distinction between goal and source is indicated by either (a) context; (b) directional verbs occurring with or without another verb, such as 'come' and 'go' as in (16b) and (16c) from Hoava; or (c) directional particles within the verb complex.

\section{TABLE 1. PREPOSITIONS AND THEIR SEMANTIC ROLES IN SOME NWS} LANGUAGES ${ }^{\dagger}$

\begin{tabular}{|c|c|c|c|c|c|}
\hline Location (LOC) & $\begin{array}{l}\text { TEOP } \\
\text { te }\end{array}$ & $\begin{array}{l}\text { BANONI } \\
\text { mo }^{*}\end{array}$ & $\begin{array}{l}\text { HOAVA } \\
\text { pa } \sim \text { ta- }\end{array}$ & $\begin{array}{l}\text { CHEKE HOLO } \\
\mathrm{ka} \text {, ke }\end{array}$ & $\begin{array}{l}\text { KOKOTA } \\
\text { ka }\end{array}$ \\
\hline Goal (ALL) & te, $(\mathrm{vo})^{\S}$ & mo & $\mathrm{pa} \sim \mathrm{ta}-$ & ka & $\mathrm{ka}$ \\
\hline Source (ABL) & te, (kahi) & mo & $\mathrm{pa} \sim$ ta- & ka & $\mathrm{ka}$ \\
\hline Time & & —\# & (pa) & $\mathrm{ka}$ & $\mathrm{ka}$ \\
\hline Accompaniment (COM) & $\mathrm{me} \sim \mathrm{mi}$ & me- $\sim$ ma- & ta- & balu- & ka, tareme- $+\dagger$ \\
\hline Instrument (INS) & & ghenai & & $\mathrm{ka}$ & $\mathrm{ka}$ \\
\hline Beneficiary & ki & $\begin{array}{l}\text { ma, min- } \sim \text { ma- } \\
\sim \text { me- } \sim \text { man- }\end{array}$ & & rayhi & $\mathrm{ka}$ \\
\hline Recipient & ki & & ta- & rayhi, ka & $\mathrm{ka}$ \\
\hline Stimulus & $\mathrm{ki}$ & & ta- & $\mathrm{ka}$ & $\mathrm{ka}$ \\
\hline Cause & & & & ka, ei-, nau- & $\mathrm{ka}$ \\
\hline Purpose & suku, men(e) & mo & & mala & mala \\
\hline Addressee & ki & & ta- & rayhi & ka \\
\hline Possession & te, $\mathrm{mi}$ & (mo) & ta- & & $\mathrm{ka}$ \\
\hline
\end{tabular}

$\dagger \quad$ Data from Mosel and Thiesen (2007), Lincoln (1976a), Lynch and Ross (2002), Davis 2003, White, Kokhonigita, and Pulomana 1988, and Palmer 2009b

+ Banoni mo is not used with proper names, which occur as obliques unmarked by an adpo-

sition (Lincoln 1976a:§7.3).

$\S \quad$ Vo and kahi may mark obliques but typically occur inside the verb complex.

\# Time reference phrases in Banoni appear to occur without any oblique marker or preposition (see Lincoln 1976a:§7.8.2).

$\dagger$ Palmer (2009b:139-140) analzes tareme- as an associative noun.

+ Palmer (2009b:363) analyzes mala as a subordinator.

31. As noted by one reviewer, Banoni has a postnominal element $v a(a)$ 'place' that could be analyzed as a postposition, as in ... mo tai ma tsina- $m v a$... (in.order go ? mother-2SG.PSSR place) 'to go to your mother' (Lincoln 1976a:§7.4). However, from Lincoln’s (1976a, 2005) discussion of $v a(a)$, it is clear that more data are needed in order to accurately describe the grammatical status of this form. 
(16) HOAVA (NEW GEORGIA, NWS, OCEANIC)
a. La sa hinaquru, hapu-ni-a sasaeri pa kabasa raro. ${ }^{32}$ go ART.SG girl cover-APPL-3SG.OBJ leaf LOC house cook
'The girl went and covered him with leaves in the kitchen.'

(Davis 2003:231)
b. Koni la gami pa hinigala. FUT go 1EXCLPL LOC garden 'We will go to the garden.'

(Davis 2003:228)
c. Mae pa Ulusage sa vaka tapuru. come LOC Marovo ART.SG ship fly 'The aeroplane came from Marovo.'

(Davis 2003:233)

2.2.2 Obliques in Mono-Uruavan. The expression of obliques in Mono-Uruavan languages is somewhat different from that in other NWS languages. First, not all adpositions in Mono-Uruavan languages are prepositional; rather, these languages have a mixture of prepositional and postpositional forms, including some forms that occur either pre- or postnominally. Second, unlike other NWS languages, these languages consistently make a formal distinction between the marker of general location and that of source (that is, they formally distinguish ablative from locative).

Table 2 sets out adpositional forms in the three Mono-Uruavan languages, giving the semantic roles of the participants each form introduces as well as its status as a preposition, a postposition, or both. ${ }^{33}$

The locative/allative adposition is consistently postpositional in all three Mono-Uruavan languages, as illustrated in (17) through (19), which also illustrate the use of the postposition to express both locations and goals.

(17) URUAVA (MONO-URUAVAN, NWS, OCEANIC)
a. iana arakao $=\mathbf{a}$ popo $=$ no-na.
fish water $=$ LOC exist $=$ IPFV-3SG.SBJ
'The fish is in the water.'
b. aria $=\mathbf{i a} \mathrm{k}-\mathrm{o} \quad$ ra-mai.
$1 \mathrm{SG}=$ LOC IRR-2SG.SBJ go-hither
'Come to me.'

(Rausch 1912:981)

(Rausch 1912:981)

(18) MONO (MONO-URUAVAN, NWS, OCEANIC)
a. Numa $=$ ng au sa-na-ta.
house $=$ LOC exist IPFV-3SG.SBJ-PRS
'He is in the house.'
b. Fanua iri-gagana famata $=\mathbf{n g}$.
men 3PL.SBJ-go village $=$ LOC
'The men went to their village.'

(Boch n.d.)

(Fagan 1986:147)

32. Symbols in the Hoava and Kubokota orthographies present in the data have their expected IPA values except $g=/ \mathrm{\gamma} /, q=/ \mathrm{g} /, v=/ \beta /$, and $n g=/ \mathrm{y} /$.

33. Table 2 gives all adpositional forms in the Mono-Uruavan languages. However, only semantic roles relevant to the discussion are shown. Other semantic roles that may be expressed by some adpositions, such as beneficiary or recipient, are not included in the table. 
(19) TORAU (MONO-URUAVAN, NWS, OCEANIC)

a. Are a-di-na koko batu-na $=\mathbf{i}$ na ate idai. and POSS-3PL.PSSR-SG.PSSM garden vicinity-3SG.PSSR=LOC SG water one 'And in their garden there was a stream.' (Palmer fieldnotes)

b. Anusa=i da-pa lao. island=LOC 1INCLPL.SBJ-IRR go 'Let's go to the island.'

(Palmer fieldnotes)

The strictly postpositional status of the locative/allative adposition also applies to the comitative adposition, which is postpositional in all three languages. This is particularly intriguing in Torau, as the comitative postposition isi, shown in (20), appears to be cognate with the comitative preposition in Kubokota, (ta) viti, exemplified in (21). In addition to the locus of comitative marking switching from prepositional to postpositional position, this may show the adpositional form itself switching from preposed to postposed position. However, this requires further investigation.

(20) TORAU (MONO-URUAVAN, NWS, OCEANIC)

$\begin{array}{lllll}\mathrm{Na} \text { idai tioni baraala isi-na } & \text { ta-di } & \text { lao. } \\ \mathrm{SG} \text { one person children } & \text { COM-3SG.PSSR } & \text { PRF-3PL.SBJ } & \text { go }\end{array}$

'One man went with all the children.'

(Palmer field notes)

(21) KUBOKOTA (NEW GEORGIA, NWS, OCEANIC)

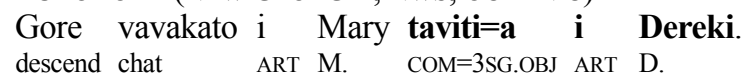

'Mary went down to tell stories with Derek.' $\quad$ (Chambers 2009)

For other categories, adpositions in the three languages display diverse structural behavior. Thus Uruava ablative tugena is a postposition, as in (22), and Mono tiga is a preposition, as in both examples in (23), while Torau iga and aga are either prepositional or postpositional, as in (24a) and (24b).

\section{TABLE 2. ADPOSITIONS AND THEIR SEMANTIC ROLES IN MONO-URUAVAN LANGUAGES ${ }^{\dagger}$}

\begin{tabular}{|c|c|c|c|c|}
\hline Location (LOC) & $\begin{array}{l}\text { MONO } \\
=\mathrm{a} \sim=\mathrm{n}^{*}\end{array}$ & $\begin{array}{l}\text { TORAU } \\
=\mathrm{ai} \sim=\mathrm{i}\end{array}$ & $\begin{array}{l}\text { URUAVA } \\
=\mathrm{ia} \sim=\mathrm{a}\end{array}$ & post \\
\hline Goal (ALL) & $=\mathrm{a} \sim=\mathrm{n}$ & $=\mathrm{ai} \sim=\mathrm{i}$ & $\begin{array}{l}=\mathrm{ia} \sim=\mathrm{a} \\
{[=\mathrm{ia} \sim=\mathrm{a}] \text { papara }}\end{array}$ & $\begin{array}{l}\text { post } \\
\text { both }\end{array}$ \\
\hline Source (ABL) & tiga & iga, aga $a^{\S}$ & {$[=\mathrm{ia} \sim=\mathrm{a}]$ tugena } & $\begin{array}{l}\text { prep } \\
\text { post } \\
\text { both }\end{array}$ \\
\hline Accompaniment (COM) & ua & isi- & kipu & post \\
\hline Instrument (INS) & ena & asana & enau & $\begin{array}{l}\text { prep } \\
\text { both }\end{array}$ \\
\hline
\end{tabular}

$\dagger \quad$ Data from Fagan (1986), Palmer (fieldnotes), and Rausch (1912).

+ In previous work the locative postposition in Mono was interpreted as having two allomorphs, $a \eta$ and $a$, the distribution of which was not known. Closer inspection of the data, including evidence from stress shift shown by Wheeler (1912), reveals that the postposition is an enclitic, with the form $=a$ in all contexts except following $/ \mathrm{a} /$, in which context the allomorph $=\eta$ occurs.

$\S \quad$ The difference between iga and aga in Torau is one of distance. Iga denotes a distant source and aga a nearby one. 
(22) URUAVA (MONO-URUAVAN, NWS, OCEANIC)

$\begin{array}{llll}\mathbf{a u}=\mathbf{a} & \text { tugena } \mathrm{e} & \text { uka. } \\ \text { wood }=\mathrm{LOC} & \mathrm{ABL} & 3 \mathrm{SG} . \mathrm{SBJ} & \text { fall }\end{array}$

'He has fallen from a tree.'

(Rausch 1912:982)

(23) MONO (MONO-URUAVAN, NWS, OCEANIC)
a. Ropu reapa ing-fa-ulul-i ama ${ }^{34}$ tiga abu. rope long 3PL.RL-CAUS-hang-TR hither ABL sky
'They lowered a long rope from the sky.'
$\begin{array}{lll}\text { b. Natu-ria } & \text { i-non-i-ri } & \text { ma tiga peta } \\ \text { son-3PL.PSSR } & \text { 3SG.SBJ-hear-TR-3PL.PSSR } & \text { hither ABL ground }\end{array}$
olova-na $=$ ng.
interior-3SG.PSSR $=$ LOC

(Fagan 1986:47)

'Their son heard them from inside the ground.'

(Fagan 1986:106)

(24) TORAU (MONO-URUAVAN, NWS, OCEANIC)
a. Balusu iga Rabaul ta-di-to lauma.
plane ABL R. PRF-3PL.SBJ-PST come
'Planes would come from Rabaul.'

(Palmer fieldnotes)

b. Buini iga di salemu-idia.

B. ABL RL.3PL.SBJ send-3PL.OBJ

'From Buin they sent them back.'

(Palmer fieldnotes)

Similarly, in Mono and Uruava, the instrumental adposition is a preposition, while in Torau it is prepositional or postpositional, as in (25)-(27).

(25) URUAVA (MONO-URUAVAN, NWS, OCEANIC)

enau bere e atun-i.

INS spear 3SG.SBJ strike-3SG.OBJ

'He struck him with a spear.'

(Rausch 1912:982)

(26) MONO (MONO-URUAVAN, NWS, OCEANIC)

Iri-lafa-i ena mua.

3PL.SBJ-hit-TR INS club

'They beat him with clubs.'

(Fagan 1986:38)

(27) TORAU (MONO-URUAVAN, NWS, OCEANIC)
a. Nau asana mane ta-gu kaisi $=a$.
1SG INS money PRF-1SG.SBJ take=3SG.OBJ
'I bought it with money.'
(Palmer fieldnotes)
b. Enele-la sidekani-na asana anua nalo
leg-3SG.PSSR pointed.leg-3SG.PSSR INS people all
pae obaka-dia.
3SG.SBJ.IRR stab=3PL.OBJ
'He jumps down and stabs people with his pointed leg.'

(Palmer fieldnotes)

34. The Mono-Uruavan languages also have reflexes of the Proto-Oceanic directional verbs that are commonly used in NWS languages to indicate the distinction between goal and source and, as here, may occur alongside an adposition that itself denotes direction. This may be a further indication that the adpositional distinction between location-goal and source is a relatively recent development; we thank Brigitte Pakendorf (pers.comm.) for this suggestion. 
A further difference between Mono-Uruavan and other NWS languages lies in the adposition stacking seen in Uruava in example (22) and the Mono example in (23b), where the ablative adposition cooccurs with the locative postposition. In Mono, the ablative preposition tiga is attested with and without the locative postposition, as a comparison of (23a) and (23b) shows. In all attested examples of ablative tugena in the limited Uruava data, it cooccurs with the locative. The same is true of the Uruava allative adposition papara, only here papara is attested as both a postposition and a preposition, as in (28). Regardless of its own position, it is always attested cooccurring with the encliticizing locative postposition.

(28) URUAVA (MONO-URUAVAN, NWS, OCEANIC)

a. papara anua=ia

ALL island $=$ LOC

'towards the island'

(Rausch 1912:982)

b. anua $=$ ia papara

island $=$ LOC ALL

'towards the island'

(Rausch 1912:982)

Another significant difference between the expression of obliques in Mono-Uruavan languages and other NWS languages is that, in these languages, while location and goal are marked by a single postposition, source is marked differently (see table 2 ). Thus Torau iga 'source (distant)', illustrated in (24a) and (24b), contrasts with $=(a) i$, which introduces both locations and goals, as shown in (29). The same pattern occurs in Mono.

(29) TORAU (MONO-URUAVAN, NWS, OCEANIC)

a. Aala mudi-na=i masini mode-la

elder.sibling back-3SG.PSSR=LOC blood modicum-3SG.PSSR

ta-to tui=sa-la.

PRF.3SG.SBJ-PST stay=SBJ-3SG.SBJ

'On the older brother's back there was a little bit of blood.'

(Palmer fieldnotes)

b. Nimu paparema $=\mathbf{i}$ pa lao.

2PL bush=LOC 2SG.SBJ.IRR go

'You go to the bush.'

(Palmer fieldnotes)

In addition to formally distinguishing locative and ablative, Uruava alone also permits distinguishing goals from locations, as the allative adposition papara in (28) shows. However, unlike the Uruava ablative tugena, which occurs with all attested source participants, papara occurs optionally with goals. In many cases, attested goals in Uruava are marked by the locative postposition alone, as in (30) (repeating [17b]). That postposition therefore retains the semantics of both location and goal.

(30) URUAVA (MONO-URUAVAN, NWS, OCEANIC)

arai $=\mathbf{a} \mathrm{k}-\mathrm{o} \quad$ ra-mai.

1SG=LOC IRR-2SG.SBJ go-hither

'Come to me.'

(Rausch 1912:981)

2.2.3 Obliques in South Bougainville. In the Papuan South Bougainville languages, obliques are denoted by nominal case suffixes or postpositions, as illustrated by (31) from 
Nasioi. Here the locative phrase 'in a clay pot' is expressed with the postposition $k o o$. Table 3 sets out the forms and semantic distinctions of postpositions and case suffixes in the four South Bougainville languages.

(31) NASIOI (SOUTH BOUGAINVILLE, PAPUAN)

... teing biang, kaikoro, bau' uutau koo ua'-e-e'nang. DEM.PL banana tapioca taro clay.pot LOC cook-2.SBJ-VOL

'....and you cook the banana, tapioca and taro in a clay pot.'

(Evans fieldnotes)

In Motuna, nominal case suffixes, including those that encode peripheral participants, are attached to the article or demonstrative within the noun phrase, as in (32a), where the comitative suffix -nno occurs with the noun phrase initial article. When neither an article nor a demonstrative is present in the noun phrase, the case suffix is attached to the final nominal modifier, or if there is no modifier to the noun itself, as in (32b). Under certain circumstances as yet not understood, the case suffix occurs on both the determiner and the head noun, as in (32c).

(32) MOTUNA (SOUTH BOUGAINVILLE, PAPUAN)
a. ... tu-ki-na tii kuraisa na-ra hoo-nno
be.3.SBJ-HAB.PST-F ART.F woman one-F ART.M-COM

po-ong ranguriwah ...

3SG.PSSR-Son man

'...a woman used to live with her (male) son ...'

(Onishi 1994:53)

b. Hiuo tuu-ki maapuk-ooto-ji-ng.

clay.pot water-INS become.full-CAUS-3.OBJ:2.SBJ-PCL.IMP

'(You all) fill the clay pot with water.'

(Onishi 1994:50)

c. tii-nno noni-nno

ART.F-COM 1EXCLPL-COM

'with us'

(Onishi 1994:221)

The examples in (33) and (34) show the use of case suffixes with obliques in Nagovisi and Buin. Note that in Buin, as in Motuna, the case suffixes can occur on a prenominal

\section{TABLE 3. POSTPOSITION AND CASE SUFFIXES IN SOUTH BOUGAINVILLE LANGUAGES ${ }^{\dagger}$}

\begin{tabular}{|c|c|c|c|c|}
\hline & NAGOVISI & NASIOI & BUIN & MOTUNA \\
\hline Location (LOC) & $\begin{array}{l}\text {-köö -göö nöö, } \\
\text {-ka }\end{array}$ & koo & $\begin{array}{l}\text {-[g]ere; -o } \sim-\mathrm{u}, \\
\text {-ga, -ge }\end{array}$ & $\begin{array}{l}\text {-kori } \sim \text {-ngori } \sim \\
\text {-jori }\end{array}$ \\
\hline Goal (ALL) & -köö -göö nöö & aape, koo & & $\begin{array}{l}\text {-kori } \sim \text {-ngori } \sim \\
\text {-jori }\end{array}$ \\
\hline Source (ABL) & -keta' $\sim$-ita' & keta $\sim$ eta & -girai & $\begin{array}{l}\text {-kitee } \sim \text {-ngitee } \sim \\
\text {-itee }\end{array}$ \\
\hline Time & & & -tano, -girai & \\
\hline Accompaniment (COM) & & ninka & & -nno \\
\hline Instrument (INS) & -ke & $\mathrm{ke} \sim \mathrm{e}$ & $-\mathrm{i} \sim-\mathrm{e}$ & $-\mathrm{ki} \sim-\mathrm{ngi} \sim-\mathrm{ji}$ \\
\hline
\end{tabular}

$\dagger \quad$ Data from Decker (1981), Rausch (1912), Laycock (2003), Griffin (1974), and Onishi (1994).

$+\quad$ The instrument marker in each of the South Bougainville languages is also used in certain contexts with the NP expressing the subject of a transitive clause, that is, as an ergative or agentive marker. This use of these forms will not be discussed further here. 
modifier, for example the possessive particle in (34b). However, little is currently known regarding the distribution of case suffixes in Buin.

(33) NAGOVISI (SOUTH BOUGAINVILLE, PAPUAN)

a. Teng manikuma kasi'-nöö' oto. ${ }^{35}$

3SG.F woman.SG garden-LOC 2/3.be

'The woman is in the garden'

(Decker 1981:58)

b. Tewöö maniku' ke'maaki' kasi'-nöö' we-ro-iee'

3PL woman.PL yesterday garden-LOC 2/3.go-PL-MIDPST

'The women went to the garden yesterday'

(Decker 1981:58)

(34) BUIN (SOUTH BOUGAINVILLE, PAPUAN)

a. Tuu minno-ge aat-u-ge-mino.

river edge-LOC sleep-1.SBJ-1DU-NRPST

'We two shall sleep by the river'

(Laycock 2003:18)

b. Ro ro-goma-yko konegu toi u-t-i.

2SG 2SG.PSSR-POSS-COM woman FUT 2/3.come-DU-IMMPST

'You come with your wife'

(Laycock 2003:123)

The South Bougainville languages display the same distinctions in the encoding of location, goal, and source as the Mono-Uruavan languages. Thus in Nagovisi, both locations and goals are expressed by the locative/allative case suffix - $k \ddot{o ̈}$ (or one of its allomorphs), as shown by (33a) and (33b). This is in contrast to source participants, which are marked by the ablative suffix -keta', as in (35). Note that in Nagovisi, the ablative suffix -keta' occurs following the locative/allative suffix (Decker 1981), resembling the use of the ablative postposition with the locative postposition in Uruava.

(35) NAGOVISI (SOUTH BOUGAINVILLE, PAPUAN)

\section{kasi'-nöö-keta'}

garden-LOC-ABL

'from the garden'

(Decker 1981:59)

In Nasioi, a single postposition encodes locations and goals, while a distinct form encodes sources. In (31), the postposition koo marks a location, while in (36a) it marks a goal. In (36b), a separate postposition, keta, denotes a source. In addition to the use of the locative postposition with goals, Nasioi also has a distinct postposition aape that can be used to encode goals in place of the locative form, as shown in (36c). ${ }^{36}$ As in Uruava, the use of the allative postposition is optional, with the locative postposition retaining both location and goal semantics. However, unlike Uruava, the allative and ablative postpositions occur alone and do not stack with the locative postposition.

35. From the examples given in Decker (1981), it appears that oto 'to be, stay' denotes present events without the expected tense ending.

36. In Buin, there is a clear distinction between the case suffixes that mark location and -girai, which marks source, but the marking of goal participants is less clear. Textual examples in Griffin (1974) suggest that goal participants may be unmarked in Buin; for example: Kigili p-ie (K. 2/3.go-IMP.PL) 'You (PL) go to Kihili' (Griffin 1974:35-36). 
(36) NASIOI (SOUTH BOUGAINVILLE, PAPUAN)

a. Duma-ri-ra emu tee teni ba-kanoo
go.back-PL-DEP.SS.IMM now DEM 3SG.F 3 SG.PSSR-POSS.SG.PSSM
te pava koo ...
ART.DEF house LOC

'When they go back to her house ...'

(Evans fieldnotes)

b. Da' taunu aape nan-i-nang, arei keta Tony noo keta ...

2SG town ALL go-2.SBJ-DES uphill ABL T. PRT ABL

'If you want to go to town from Tony's place uphill ...'

(Evans fieldnotes)

c. ... ba-taata pora' aape be-u'ung.
3SG.PSSR-elder.brother bush ALL go.2/3.SBJ-RMPST
'... and his older brother went to the bush (i.e., the garden).'

(Evans fieldnotes)

As with the Nagovisi comitative case marker in (32c), the Nasioi comitative postposition ninka can occur on both the determiner and the head noun, as in (37).

(37) NASIOI (SOUTH BOUGAINVILLE, PAPUAN)

Narung ninka pankara ninka nan-aa-u'nung.

one.M COM old.man COM go-3.SBJ-RMPST

'They went with one old man.'

(Hurd 1977:128)

In summary, South Bougainville languages encode obliques with postpositions or suffixes, distinguishing between locations and sources while typically treating locations and goals alike. NWS languages instead typically use prepositions to encode obliques, and do not distinguish between sources and locations on the one hand and goals on the other. In contrast, Mono-Uruavan languages resemble South Bougainville languages in using distinct forms to encode sources on the one hand, and goals and locations on the other. In addition, Uruava and Mono resemble South Bougainville Nagovisi in a more fine-grained way, by stacking the ablative marker onto the locative form. Uruava also resembles Nasioi in a more fine-grained way by employing a distinct allative postposition that may, but need not, occur with goals, with the locative postposition retaining both location and goal semantics. Mono-Uruavan further resembles South Bougainville by employing postpositions rather than standard NWS prepositions. However, this is variable, with some oblique functions encoded by prepositions in one or more language, but by postpositions in others, and by some forms in some languages occurring in both preposed and postposed position. Given the use of prepositions in Mono-Uruavan's closest genetic relatives, this variation suggests a shift from prepositions to postpositions in languages in contact with the postpositional/suffixing South Bougainville family.

2.3 POSSESSIVE CONSTRUCTIONS. Possessive constructions in MonoUruavan languages also appear to have undergone contact-induced change: first, in terms of the order of the possessor and possessum; and second, with regard to the marking of number of the possessum.

2.3.1 Possessive constructions in NWS. Possessive constructions in NWS languages are typical of Oceanic languages (see Lichtenberk 1985, Lynch, Ross, and Crow- 
ley 2002), in that they have direct and indirect constructions, associated with inalienable and alienable possessive relationships, respectively. ${ }^{37}$ In direct possessive constructions, like the examples in (38) from Kubokota, the possessor is indexed by a suffix attached directly to the noun denoting the possessum. The possessive suffix/enclitic may be the only expression of the possessor participant in the phrase, as in (38a). When the possessor is overtly expressed by an NP, then the order is possessum followed by possessor, as in (38b). Direct possessive constructions in Oceanic languages tend to encode kinship and part-whole relationships, spatial relations, physical attributes, or mental states, as well as ownership of certain culturally-significant items (Lichtenberk 1985; Lynch, Ross and Crowley 2002, Palmer 2008).

(38) KUBOKOTA (NEW GEORGIA, NWS, OCEANIC)

a. ... pa kori lima matau=di.

'....in their right hands.'

(Chambers 2009:65)

b. na pudupudu $=$ di na tinoni

ART bone=3PL.PSSR ART person

POSSESSUM POSSESSOR

'people's bones'

(Chambers 2009:65)

In indirect possessive constructions, the possessor suffixes are attached to a particle preceding the noun denoting the possessum. ${ }^{38} \operatorname{In}$ (39a) from Kubokota, for example, the 1SG possessor marker - gu attaches to the possessive particle ge, and is followed by ngiru 'coconut', the noun expressing the possessum. Most Oceanic languages have more than one possessive classifier, each classifier denoting different kinds of possessive relationships. Kubokota has a consumable possessive classifier ge- $\sim g a$ - that is used with "consumed" possessive relationships, including items to be eaten or drunk, as well as cigarettes and betelnut (Chambers 2009:66-67), glossed here as CNSPOSS. ${ }^{39}$ In Kubokota, the "consumed" indirect possessive construction contrasts with a second indirect construction expressing general (that is, nonconsumed) alienable possession, as shown in (39b). Here the possessor participant is indexed by a possessive pronominal element, for example, the 1SG form qua in (39b). Historically, this general indirect construction involved a clearly separable particle, reconstructable as *no-for Proto-NWS, and that is still the case in most subgroups of NWS. ${ }^{40}$ However, in the New Georgia subgroup to which Kubokota belongs, these are no longer synchronically divisible into a possessive particle and a possessor suffix. ${ }^{41}$ As with direct possession, in these constructions the order of participants is again possessum followed by possessor, as in (39c).

37. Many Oceanic languages have a third, prepositional, possessive construction (Lichtenberk 1985), but these types of structures are not relevant to the present discussion.

38. These particles are usually analyzed as relational classifiers (Lichtenberk 1983, 2009). In some NWS languages, these may in fact be the syntactic head of the NPs in which they occur (Palmer and Brown 2007).

39. Chambers (2009) glosses this item as ED. However, as it encodes possession of items consumed in any way, we have adopted CNSPOSS, slightly modifying Palmer's (2009b) gloss CNSMPOSS for the corresponding form in Kokota.

40. The historical origins of the possessive pronouns in Kubokota is most clearly seen in the 3rd person singular and 1st person plural inclusive forms nana and nada, respectively. 
(39) KUBOKOTA (NEW GEORGIA, NWS, OCEANIC)
a. na ge-qu ngiru
ART CNSPOSS-1SG.PSSR coconut
'my coconut'
b. na qua guguzu
ART 1SG.PSSR village
'my village'
$\begin{array}{lllll}\text { c. na } & \text { qua } & \text { viri } & \text { ara } \\ \text { ART } & \text { 1SG.PSSR } & \text { tobacco } & \text { 1SG } \\ & \text { POSSESSUM } & & \text { POSSESSOR }\end{array}$
'my tobacco'

(Chambers 2009:67)

(Chambers 2009:68)

Crucially for the comparison with Mono-Uruavan languages below, in NWS languages outside Mono-Uruavan, the number of the possessum is not expressed within the possessive construction, as illustrated by the examples in (40) from Kubokota. In isolation, an NP such as that in (40a) is ambiguous in terms of the number of the possessum, although the number of a possessum may be recoverable from formal marking elsewhere in the clause, as in (40b), where plurality of the possessum is indicated grammatically by the object enclitic =ria on the verb. However, it is not indicated in any way within the possessive construction itself.

(40) KUBOKOTA (NEW GEORGIA, NWS, OCEANIC)
a. na dia koburu
ART 3PL.PSSR child
'their child/children'
b. ... qari va-iu=ria na dia koburupa leo ruma...
3PL.SBJ.RL CAUS-wash=3PL.OBJ ART 3PL.PSSR child LOC inside house
'...they washed their babies in the house...' (Chambers 2009:82)

2.3.2 Possessive constructions in Mono-Uruavan. Mono-Uruavan languages employ the same direct and indirect types of possessive constructions as other NWS languages. However, in all Mono-Uruavan languages, the order of possessor and possessum is the reverse of that found elsewhere in NWS. Aside from this order reversal, possessive constructions in Mono resemble those found elsewhere in NWS. In the direct possessive construction in (41a), the noun ifa 'sister-in-law' itself takes the 3SG possessor suffix -na. The direct construction in Mono is used to express inalienable possessive relationships including kinship terms, body-part terms, locations, and a number of other items (Fagan 1986:26-27). In the indirect possessive construction in (41b), the possessor suffix -gu ' 1 SG.PSSR' is attached to a possessive particle preceding the possessum noun, in this case the "consumed" particle $e$ - Mono retains a distinction between "consumed" and "nonconsumed" possession, the latter expressed in Mono by the innovated Mono-Uruavan possessive particle $s a-$, as in (41c).

41. Chambers (2009) also analyzes the "consumed" possessive construction as comprising a synchronically indivisible possessive pronoun (for example, gequ '1SG.POSS', gemu '2SG.POSS', gana '3SG.POSS'). Historically, however, these forms in Kubokota, and cognate forms in other New Georgia languages, reflect possessive particles with the possessor suffixes/enclitics. 
What is different about Mono possessive constructions in comparison with those of other NWS languages is the order of constituents. That is, in Mono the possessor precedes the possessum, as the examples in (41) show.

(41) MONO (MONO-URUAVAN, NWS, OCEANIC)
a. I-gagana ma
ga batafa
3SG.SBJ.RL-go hither
ABS woman
ifa-na.
sister-in-law-3SG.PSSR
POSSESSOR POSSESSUM

'The woman's sister-in-law came.'

(Fagan 1986:22)
b. Mafa e-gu iana maranatu.
1SG CNSPOSS-1SG.PSSR fish fish.sp
POSSESSOR POSSESSUM

'My fish is the maranatu.'

(Fagan 1986:30)
c. Maang sa-mia ka kanega baoi
2PL GENPOSS-2PL.PSSR PL $\sim$ man shark
POSSESSOR POSSESSUM
i-fa-gaful-i-ri.
3SG.SBJ.RL-CAUS-finish-TR-3PL.OBJ
'A shark has made an end of your husbands.'

(Fagan 1986:30)

While possessive constructions in Mono resemble those of other NWS languages, with the exception of the PSSR + PSSM order, Torau and Uruava differ from other NWS languages, even their immediate sister Mono, in several important aspects of their possessive constructions. Both do display the distinct direct and indirect possessive constructions found throughout NWS, as (42) and (43) show. Both also share with Mono the innovated PSSR + PSSM order, as in (42) and (43).

(42) TORAU (MONO-URUAVAN, NWS, OCEANIC)

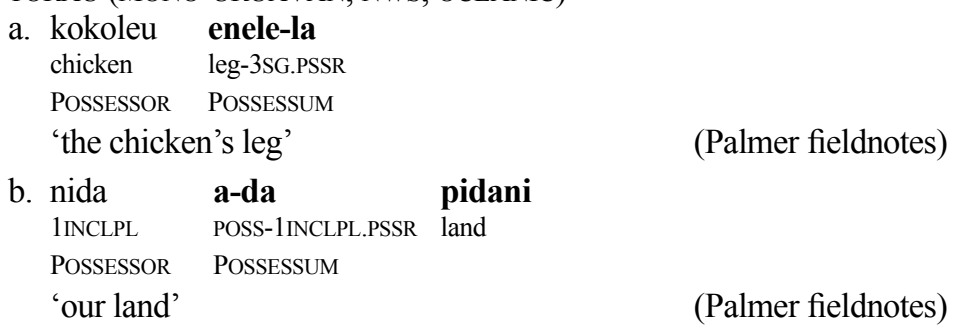

(43) URUAVA (MONO-URUAVAN, NWS, OCEANIC)
a. aro
patu-mu
2SG head-2SG.PSSR
POSSESSOR POSSESSUM
'your head'
man-chief SG.PSSM-3SG.PSSR people
POSSESSOR POSSESSUM
'the chief's people'
b. soni-tuna e-na vanua

(Allen and Hurd 1963)

(Oliver 1938-39)

In two other important respects, Uruava and Torau differ from other NWS languages, even Mono. Unlike most other NWS languages, the distinction between classes of indi- 
rect possessive relations has been neutralized. In Torau, for example, the particle $a$ - (and its allomorph $e$-) is used with all indirect possessive relations, whether the item is intended to be consumed, as in one possible reading of (44), or not, as in the other reading of (44) and in (42b). In Uruava, reflexes of both "consumed" and general indirect paradigms have been retained, as we will see below. However, they no longer have their original function, and no distinction between "consumed" and "nonconsumed" possession is expressed in Uruava.

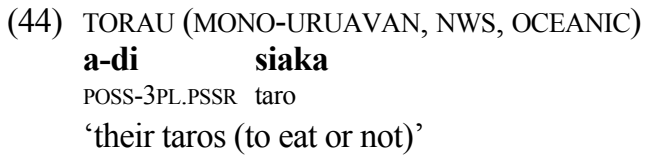

(Palmer fieldnotes)

Neutralizaton of classes of indirect possession has occurred sporadically elsewhere in Oceanic, including in a small number of NWS languages outside Mono-Uruavan, such as Banoni. More striking, and seemingly unique in Oceanic, is the fact that in Torau and Uruava the number of the possessum is obligatorily indicated within the indirect possessive constructions, and in the case of Uruava, also in the direct construction in certain contexts. However, intriguingly, the two languages mark possessum number in different ways.

In indirect possessive constructions in Uruava, a preposed particle indexes the person and number of the possessor, as elsewhere in NWS. However, although reflexes of both "consumed" and general indirect paradigms occur, the original functional distinction has been neutralized, and the morphology coopted to express possessum number. A paradigm largely reflecting the Proto-NWS "consumed" paradigm is used with singular possessum nouns, ${ }^{42}$ while a paradigm reflecting the general paradigm is used with plural possessum nouns. These paradigms are shown in tables 4 and 5 (data in both tables from Rausch 1912 and Oliver 1938-39). In addition to using reflexes of the general paradigm, a plural possessum is marked by the suffix -gi attached to the possessive particle, as illustrated by the difference between (45a) and (45b) and in the plural forms in (46b) and (46d).

TABLE 4. URUAVA INDIRECT POSSESSION WITH SINGULAR POSSESSUM

$\begin{array}{lllll}\text { Possessor } & \text { 1EXCL } & \text { 1INCL } & 2 & 3 \\ \text { SG } & \text { e-gu } \sim \text { go } & - & \text { e-mu } \sim \text { mo } & \text { e-na } \\ \text { PL } & \text { e-mau } & ? & \text { e-mu } & \text { e-di }\end{array}$

\section{TABLE 5. URUAVA INDIRECT POSSESSION WITH PLURAL POSSESSUM}

$\begin{array}{lllll}\text { Possessor } & \text { 1EXCL } & \text { 1INCL } & 2 & 3 \\ \text { SG } & \text { go-gi } & - & \text { mo-gi } & \text { na-gi } \\ \text { PL } & \text { ma-gi } & ? & \text { mi-gi } & \text { di-gi }\end{array}$

42. The exceptions are the alternative $1 \mathrm{SG}$ and $2 \mathrm{SG}$ forms shown in table 4 , where the alternative form in the singular posssessum paradigm is identical to that marked with $-g i$ in the plural possessum paradigm. This is illustrated by the use of $g o$ in (45a) in contrast with $e$ - $g u$ in (46a) and (46c). Equivalent alternates do not occur in other person/number categories. The distribution of the alternates in $1 \mathrm{SG}$ and $2 \mathrm{SG}$ is not known. 
(45) URUAVA (MONO-URUAVAN, NWS, OCEANIC)
a. go bere
1SG.PSSR spear
'my spear'
b. go-gi bere
1SG.PSSR-PL.PSSM spear
'my spears'

(Rausch 1912:975)

(Rausch 1912:975)

This possessum number marking on the possessive particle is entirely independent of normal nonpossessive number marking in the language. For most classes of nouns, no overt plural marking is possible outside of the possessive construction, as with bere in (45b). However, terms for humans are marked for plurality. Most kinship terms are marked for plurality by reduplication, as with $a \beta u \sim a \beta u t e i$ 'brothers-in-law' in (46b). Other nouns denoting humans may be marked for plural with the particle buri, as with buri maru 'women' in (46d). This is independent of number marking associated with possession: aßu aßutei may occur in nonposssessive constructions meaning 'brothersin-law', and buri maru may occur without a possessor, meaning 'women'.

(46) URUAVA (MONO-URUAVAN, NWS, OCEANIC)
a. e-gu aßutei
SG.PSSM-1SG.PSSR brother-in-law
'my brother-in-law'
b. go-gi aßu aßutei
1SG.PSSR-PL PL brother-in-law
'my brothers-in-law'
c. e-gu maru
SG.PSSM-1SG.PSSR woman 'my wife'
d. go-gi buri maru
1SG.PSSR-PL.PSSM PL woman
'my wives'

(Rausch 1912:976)

(Rausch 1912:976)

(Rausch 1912:976)

(Rausch 1912:976)

In Torau, overt morphology indexing possessum number occurs in only one category of the feature, but unusually, it is singular possessums that are marked, rather than the plural ones, at odds with a typological tendency for singular to be the unmarked number. In (47a), the singular possessum is indexed by the -na suffix on the possessive particle. This is in contrast to (47b), where the number of the possessum is not overtly marked, giving an obligatory plural interpretation.

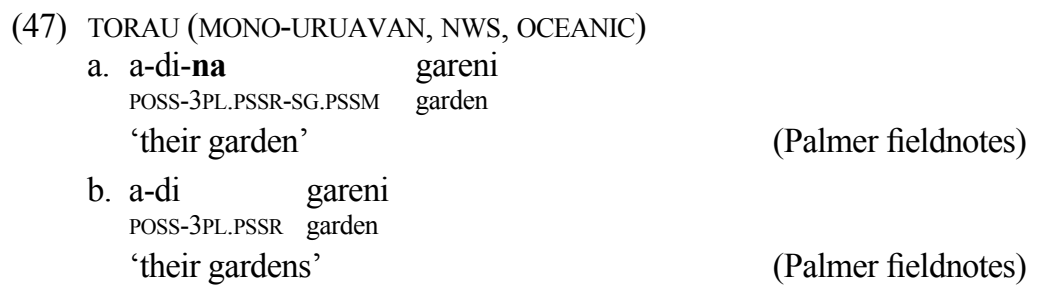


2.3.3 Possessive constructions in South Bougainville. The characteristics of possessive constructions in Mono-Uruavan languages that differ from those of other Northwest Solomonic languages resemble features of possessive constructions in the Papuan South Bougainville languages.

Like Mono-Uruavan languages, the South Bougainville languages have direct and indirect possessive constructions, and a tendency for PSSR + PSSM constituent order. In these languages, the semantic distinction that is grammatically relevant for possessive constructions appears to be one between kinship relations and all other possessive relationships, rather than a broader inalienable versus alienable distinction.

For example, in Buin, possessive relationships with kinship terms are encoded by a set of prefixes indexing the person and number of the possessor and attached to the noun denoting the possessum, in a direct construction, as in (48). ${ }^{43}$ Other kinds of possessive relations in Buin are indicated by a genitive case suffix, attached to the possessor noun, as in (49). Note that in Buin the order of participants is possessor followed by possessum.

(48) BUIN (SOUTH BOUGAINVILLE, PAPUAN)
a. ru-ro
b. poo-ro
c. pau-ro
1SG.PSSR-daughter
3SG.PSSR-daughter
3PL.PSSR-daughter
'my daughter'
'his/her daughter'
'their daughter'

(Laycock 2003:195)

(49) BUIN (SOUTH BOUGAINVILLE, PAPUAN)

konegu-yke

woman.SG-GEN

POSSESSOR

taine

coconut.leaf.basket

POSSESSUM

'the woman's basket'

(Laycock 2003:xv)

In Motuna, the expression of possessive relationships is more complex. Onishi (1994) describes three kinds of possessive structures for Motuna: (i) kinship possessive constructions; (ii) classifier possessive construction; and (iii) "other" possessive constructions. ${ }^{44}$ Kinship possessive relationships in which the possessum is denoted by a nondyadic kin term are expressed in Motuna by a direct construction, where a pronominal possessor prefix attaches to the noun denoting the possessum, as shown in (50). ${ }^{45} \operatorname{In}(51)$, the possessor participant is also denoted by an independent noun, showing that the order of constituents is possessor followed by possessum.

(50) MOTUNA (SOUTH BOUGAINVILLE, PAPUAN)
a. n-uka
1SG.PSSR-mother
b. po-oku
c. noni-kuku-uri'
'my mother'
3SG.PSSR-mother
1EXCLPL.PSSR-mother-PCL
'his/her mother'
'our mothers'

(Onishi 1994:241)

43. In Buin, as well as the other three South Bougainville languages, the 1sG forms of possessed kinship terms are often irregular or unmarked. This issue is not relevant to our discussion of possessive constructions and so will not be described in more detail here.

44. Possessive relationships, including body part relations, the relationship between a person and their place of origin, and between an object and its origin or time, can also be expressed by local attributive constructions in Motuna (see Onishi 1994:245ff.). This structure is not relevant to the present discussion and will not be discussed here.

45. Dyadic kinship terms, such as $k u$ 'mother and child', behave differently from nondyadic kin terms (see Onishi 1994:242f), but they are not relevant to the present discussion. 
(51) MOTUNA (SOUTH BOUGAINVILLE, PAPUAN)

$\begin{array}{lll}\text { hoo } & \text { kuraisa } & \text { po-moro } \\ \text { ART.M } & \text { young.woman } & \text { 3SG.PSSR-relative.PCL } \\ & \text { POSSESSOR } & \text { POSSESSUM } \\ \text { 'the young woman's }\end{array}$

'the young woman's relatives'

(Onishi 1994:241)

The classifier possessive construction in Motuna is an indirect construction in which pronominal prefixes denoting the possessor participant are attached to a classifier that also carries morphology indexing the class of the possessum. For example, in (52a) the 1SG possessor is indicated by the prefix ngo- that occurs with the classifier for fruit, namely mung. The possessum is also denoted by the noun moo 'coconut', which precedes the classifier ${ }^{46}$ As shown in (52b), the classifier may be the only expression of the possessum within a possessive construction.

(52) MOTUNA (SOUTH BOUGAINVILLE, PAPUAN)

a. Ong moo ngo-no-mung roki=manni mutih-ah. DEM.M coconut 1SG.PSSR-LINK-CLF.fruit really ${ }^{47}$ be.tasty-PART 'My coconut (i.e., from my tree) is certainly tasty.'

(Onishi 1994:244)

b. Hoio u'kisa pi-i-ng hoo-nno poko-no-po ... H. long.ago go.3.SBJ-RMPST-M ART.M-COM 3SG.PSSR-LINK-CLF.people 'Hoio went with his people long ago ...'

(Onishi 1994:244)

The order of possessor and possessum constituents in this type of construction in Motuna is not entirely clear. Onishi (1994:245) notes that a 3rd person possessor prefix can be expanded by a full noun, which occurs preceding the classifier. This can be seen from (53), where Maawo 'Maawo' precedes the classifier element poko-na-pa 'his shelter'.

(53) MOTUNA (SOUTH BOUGAINVILLE, PAPUAN)

$\begin{array}{llll}\text { Ong howo } & \text { hoo } & \text { Maawo } & \text { poko-na-pa. } \\ \text { DEM.M house } & \text { ART.M } & \text { M. } & \text { 3SG.PSSR-LINK-CLF.shelter } \\ & & \text { POSSESSOR } & \text { POSSESSUM }\end{array}$

'This house is Maawo's shelter (in contrast to other houses).'

(Onishi 1994:245)

Classifier possessive constructions in Motuna are used to express object-owner relationships (52a), and associative relationships and social relations between a person and others "belonging" to them (52b). Possessive relationships tend to be expressed with this construction type to indicate a notion of contrast. Thus the possessive phrase

46. The possessive particle in indirect possessive constructions in Oceanic languages is also often called a classifier (see, however, Palmer and Brown 2007). However, it is important to note that classifiers in Motuna are very different from these Oceanic forms. As well as this possessive function, classifiers in Motuna have the numeral and demonstrative functions that have been described for classifier systems cross-linguistically. Thus they also occur in nonpossessive noun phrases combined with the bound forms of demonstratives, articles, numerals, and some adjectives (Onishi 1994:162ff).

47. Onishi (1994) consistently presents the form roki=mami with the single gloss 'really'. It is not clear what analysis is intended so the original has been retained.

48. Although the possessum is also denoted by an independent noun here, occurring clauseinitially, the clause is an equative clause with ong howo 'that house' as the argument and hoo Maawo poko-na-pa 'Maawo's shelter' as the nominal predicate (see Onishi 1994:63). 
in (52a) has the meaning of 'the coconut I own' in contrast to coconuts from other people's trees (Onishi 1994:244).

For noncontrastive expression of nonkin possession, a third construction exists in Motuna, illustrated in (54a). In this type of structure, the possessor participant is denoted by a possessive pronoun that agrees in gender with the following possessum. In (54a), $n g a$, the 1SG possessive pronoun, takes the feminine suffix $n a$, and is followed by the possessum kuraisa 'woman'. In this construction, a 3rd person possessive pronoun denoting the possessor can be expanded by a lexical noun, as in (54b), where both Maawo 'Maawo' (a person's name) and poko-ng 'his' indicate the possessor. It is also possible for the possessor to be expressed solely by a lexical noun, which then agrees in gender with the possessum, as in (54c). ${ }^{49}$

(54) MOTUNA (SOUTH BOUGAINVILLE, PAPUAN)
a. ana nga-na kuraisa
DEM.F 1SG.PSSR-F woman
POSSESSOR POSSESSUM
'this wife of mine'
b. hoo Maawo poko-ng munu
ART.M M. 3SG.PSSR-M body
POSSESSOR POSSESSUM
'Maawo's body'
c. tii Maawo-ni pokoring
ART.DIM M.-DIM tail
POSSESSOR POSSESSUM
'Maawo's tail'

(Onishi 1994:246)

(Onishi 1994:247)

(Onishi 1994:247)

This possessive construction in Motuna is used to express body part and other partwhole relations, personal characteristics, object-owner relationships, and relationships between a group of people and an object or between more than one group of people (Onishi 1994:248). Examples in (54) demonstrate the constituent order of PSSR + PSSM. In this type of possessive construction, it is also possible for the possessum to precede the possessor, as in (55). The difference between these two orders, as with other pre- and post-head nominal attributes in Motuna, is that the possessor follows the possessum when it describes the referent of the noun, and precedes the possessum when it identifies it (Onishi 1994:224, 239).

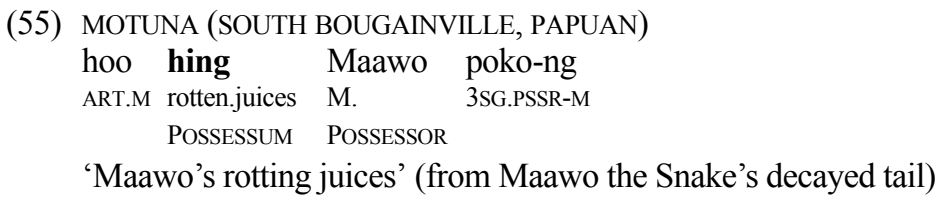

(Onishi 1994:246)

Nasioi and Nagovisi, like Buin, have two types of possessive constructions: one that encodes kinship relationships, and another used with all other kinds of possessive relationships. As in Motuna and Buin, in Nasioi and Nagovisi kinship possessive relationships are indicated by pronominal possessor prefixes attached to the noun denoting the

49. The form of the article here indicates the diminutive gender of the possessum (pokoring 'tail'), and the possessor NP, Maawo-ni, takes the diminutive ending -ni in agreement. 
possessum: compare the examples in (56) and (58). In Nasioi, when both participants in a "kinship" possessive construction are expressed by nominals, then the order appears to be possessor followed by possessum, as illustrated in (57). ${ }^{50}$

(56) NASIOI (SOUTH BOUGAINVILLE, PAPUAN)
a. nó-rang
b. dau-rang
c. biu-rang
1SG.PSSR-daughter
2SG.PSSR-daughter
3PL.PSSR-daughter
'my daughter'
'your daughter'
'their daughter'

(Rausch 1912:118)

(57) NASIOI (SOUTH BOUGAINVILLE, PAPUAN)

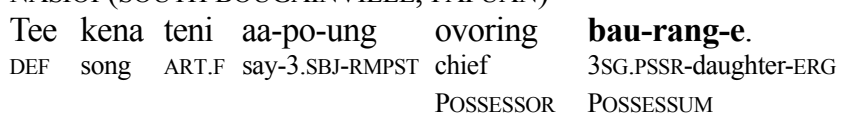

'She sang the song, the chief's daughter.'

(Evans fieldnotes)

NAGOVISI (SOUTH BOUGAINVILLE, PAPUAN)
a. nn-obe
b. wa'-robe
c. vii'-robe

1SG.PSSR-grandchild

3SG.PSSR-grandchild

3PL.PSSR-grandchild

'my grandchild'

'his/her grandchild'

'their grandchild'

(Decker 1981:48)

The second possessive construction in Nasioi and Nagovisi, involving nonkinship terms, is an indirect construction similar to the "other" possessive construction in Motuna shown in (54). Examples in (59) illustrate this construction in Nasioi. Here possessor prefixes are attached to a possessive particle that follows the possessor noun. The possessive prefixes index the person and number of the possessor. ${ }^{51}$ Thus $b a$ - '3SG.PSSR' in (59a) contrasts with $b i$ - '3PL.PSSR' in (59b). The possessive particle also indexes the number of the possessum, so the final $-a$ ' $\mathrm{SG}$ ' in (59a) contrasts with the final $-i$ ' $\mathrm{PL}$ ' in (59c). Unusually, the possessive particles therefore index number of both the possessor and the possessum. Rausch (1912:119) comments that the usual order of participants is possessor followed by possessum, but that the possessum may also precede the possessor, as in danko naning ba-kan- $a$ (spear man 3SG.PSSR-POSS-SG.PSSM) 'the man's spear'.

(59) NASIOI (SOUTH BOUGAINVILLE, PAPUAN)

$\begin{array}{ll}\text { a. naning ba-kan-a } & \text { danko } \\ \text { man.SG 3SG.PSSR-POSS-SG.PSSM } & \text { spear } \\ \text { POSSESSOR } & \text { POSSESSUM } \\ \text { 'the man's spear' } & \end{array}$

(Rausch 1912:119)

50. We have a limited number of examples of Nasioi "kinship" possessive constructions in which both the possessors and possessums are expressed by nouns. It is possible that additional data may indicate that a PSSM + PSSR order also occurs.

51. Hurd (1977:154ff.) provides a slightly different analysis of the Nasioi possessive forms: (i) he gives a more fine-grained analysis for the possessive prefixes ( $n$ - first person, $b$ - third person; - $\varnothing$ singular possessor with $n-,-a$ singular possessor with $d$ - and $b$ - when occurring before vowels and voiceless consonants); (ii) he labels $k a$ an intensity marker; and (iii) he describes - $n a$ as a "projective" derivational suffix, the form of which is determined by adjacent morphemes. The data presented in Rausch (1912) and Hurd (1977), as well as those collected by Evans, suggest that more detailed analysis is needed in order to gain a more complete understanding of Nasioi noun phrases and their morphology, including possessive noun phrases. 


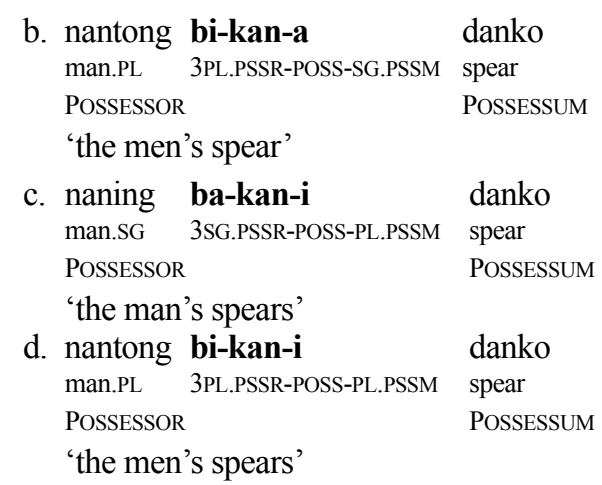

(Rausch 1912:119)

(Rausch 1912:119)

Nagovisi appears to have an identical construction, with the possessive particle again occurring before or after the noun denoting the possessum, as shown in (60). Decker (1981:55) notes that the initial possessive particle, (60b), emphasizes the possessor's ownership of the possessum. Decker $(1981: 44-45,55)$ analyzes the possessive particle as a possessive pronoun that takes a suffix -pöö to indicate a plural possessum. However, from the paradigms she presents (Decker 1981:44-45), the Nagovisi forms display the same kind of alternations for person and number of the possessor and number of the possessum as in Nasioi: $n g$-gang (1SG.PSSR-POSS.SG.PSSM) 'my thing', $n g$-gam-pöö (1SG.PSSR-POSS-PL.PSSM) 'my things', la-kang (2SG.PSSR-POSS.SG.PSSM) 'your (SG) thing', and la-kam-pöö (2SG.PSSR-POSS-PL.PSSM)'your (SG) things'.

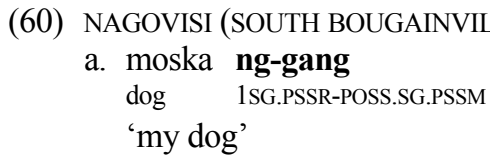
E, PAPUAN)
b. ng-gang moska 1SG.PSSR-POSS.SG.PSSM dog ' $m y$ dog'

(Decker 1981:55)

In summary, the order of possessor and possessum in the Mono-Uruavan languages is right-headed, that is, PSSR + PSSM. This is at odds with the reverse order found elsewhere in NWS, but agrees with the order found in South Bougainville languages. In addition, Uruava and Torau display an innovative strategy, apparently unique in Oceanic, of marking number of the possessum noun on the indirect possessive particle, resembling the marking of possessum number in Nasioi and Nagovisi (but not Buin or Motuna). It is noteworthy that this is found in Uruava and Torau, which have a long history of contact with Nasioi (both are located in enclaves surrounded by Nasioi speakers), which also displays this phenomenon, while their immediate sister Mono does not. Instead, Mono has a history of contact with Buin, which lacks the phenomenon. This suggests that this innovation arose in Uruava and Torau since the diversification of Proto-Mono-Uruavan, specifically as a result of contact with Nasioi. Moreover, the fact that Torau and Uruava have adopted different strategies for expressing the distinction suggest that they have independently innovated the distinction, further supporting the hypothesis that this is a development in Torau and Uruava resulting from Nasioi contact, rather than a Mono-Uruavan level innovation. ${ }^{52}$

52. This accords with what is known of the timing of contact between the two languages and Nasioi. Torau is known to have come into contact with Nasioi due to migration into the Nasioi area in the early to mid nineteenth century, while Uruava appears to have been in situ for much longer. 
3. CONTACT-INDUCED CHANGE IN MONO-URUAVAN. The linguistic data presented here from Mono-Uruavan and other NWS languages and from South Bougainville languages provide support for the hypothesis that at least some of the linguistic diversity among NWS languages is the result of contact-induced change and reflects social contact among speakers of Austronesian and Papuan languages. That is, we argue that the innovative features of Mono-Uruavan described in the preceding section, where these three languages differ from other NWS languages and resemble the Papuan South Bougainville languages, are changes motivated by linguistic contact.

Table 6 summarizes the linguistic features of Mono-Uruavan languages that display contact-induced change. Characteristics of clause order, the expression of obliques, and possessive constructions are given for Mono-Uruavan languages (middle columns), other NWS languages (left-hand column) and the South Bougainville languages (righthand columns). The grey shading highlights those characteristics that Mono-Uruavan languages share with their NWS sister languages (for example, the semantic distinction between alienable and inalienable possessive relationships), and those that they share with their neighboring South Bougainville languages (for example, SOV unmarked clause order). Since table 6 consists only of those linguistic features discussed in the paper, ones selected because of their atypical nature among Oceanic languages, it gives the impression that Mono-Uruavan languages are much more similar to South Bougainville languages than to other NWS languages. While this is true to some extent, it should be noted that were additional linguistic features included in table 6 (for example, valencychanging morphology or verbal argument agreement), Mono-Uruavan languages would appear more similar to their sister NWS languages.

3.1 COMMON OR PARALLEL CHANGE? Table 6 also presents a picture of contact-induced changes, which aside from possessum number marking and adposition stacking, occur in all three Mono-Uruavan languages, perhaps reflecting shared innovations of the languages' common ancestor. However, closer examination reveals that the history of contact-induced change in these languages is more complex than it first appears.

All three Mono-Uruavan languages have developed the South Bougainville pattern of unmarked SOV clause order. Thus it is reasonable to hypothesize that this change occurred once, at a time when these languages formed a single speech community. However, certain differences in the word order patterns of Torau and Mono suggest that although this change may have begun before the break-up of these languages, it has continued in different ways in each language. For example, Mono has a much greater frequency of non-verb-final clauses than Torau, and in Mono different clause order patterns are associated with the presence or absence of the absolutive case marker..$^{53}$

The innovative order in possessive constructions of PSSR + PSSM is also found in all three Mono-Uruavan languages, and so may reflect an early shared innovation. However, the innovative marking of number of the possessum found in Mono-Uruavan languages

53. Fagan (1986) notes that SV and VS orders occur with equal frequency in Mono intransitive clauses, while SOV and SVO are both frequent with transitive clauses. Preliminary analysis of Torau texts indicates that verb-final clause order occurs more than twice as often as non-verbfinal clauses. (This is based on a sample of 284 clauses in three different narratives with 98 verb-final clauses and 41 non-verb-final clauses; the remaining 145 clauses were nonverbal or consisted of only a verb complex.) 


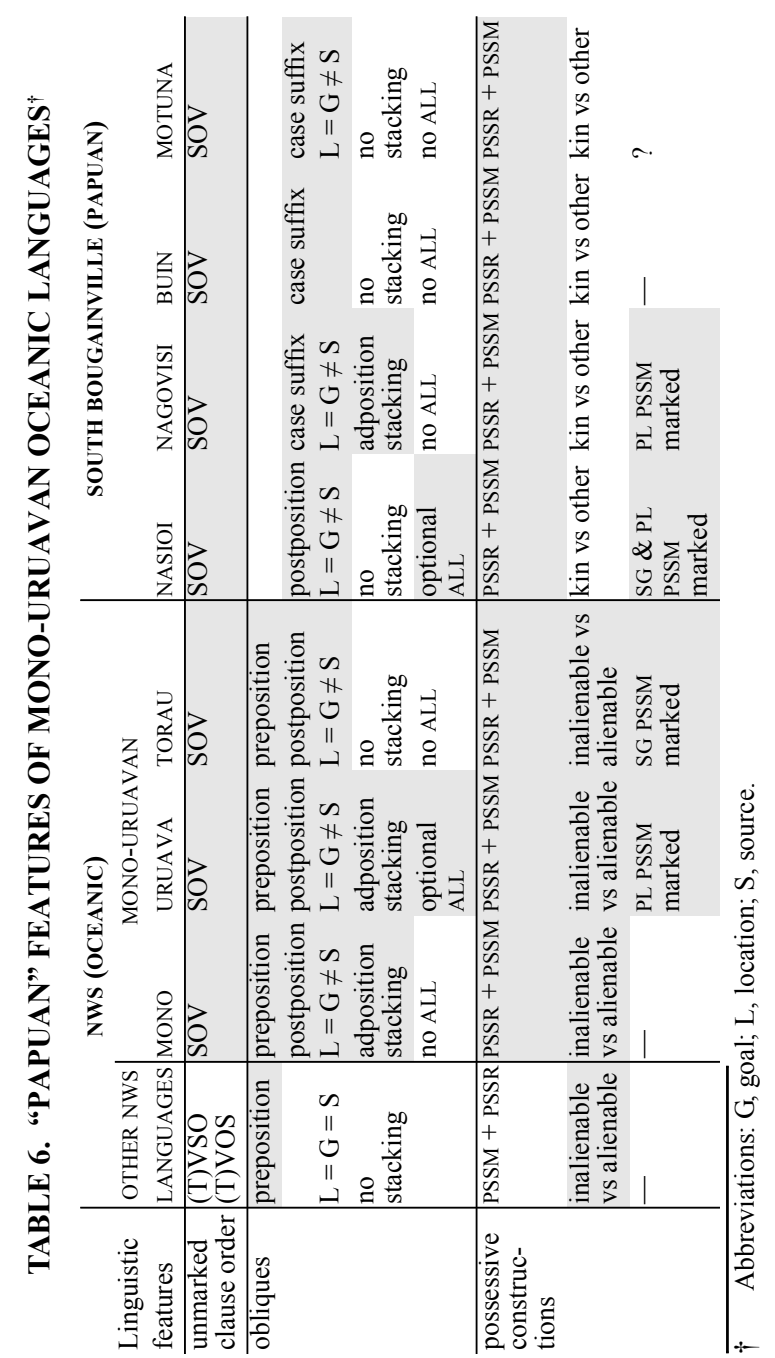


appears to reflect contact-induced change influenced specifically by Nasioi or Nagovisi. ${ }^{54}$ Both Uruava and Torau, but not Mono, have developed this structural pattern, but the form of the number marking is different, suggesting that this innovative structural pattern developed independently in the two languages..$^{55}$

The South Bougainville structural pattern of a noun followed by its oblique marker (that is, a postposition or relevant case suffix) also occurs in all Mono-Uruavan languages, along with a shift to the South Bougainville semantic organization, where location and goal are expressed by one form and source by another. ${ }^{56}$ However, as can be seen from table 2 , there is variation among the three Mono-Uruavan languages in both structure and form.

All three languages have developed a locative/allative postposition. Torau $=(a) i$ and Uruava $=(i) a$ appear to be a common innovation in form, and they most likely reflect Proto-Oceanic *i-ai 'preposition + locative anaphor' (Lynch, Ross, and Crowley 2002:104). ${ }^{57}$ Thus the Torau and Uruava locative/allative postposition represents the development of the structural sequence noun + postposition through the reanalysis of a nonadpositional form of Oceanic origin. The form of the Mono locative/allative postposition, $=a \sim=\eta$, likely has a different origin.

The differences in form and/or structure of the other Mono-Uruavan adpositions point to independent changes, rather than a single common innovation. All three languages have a comitative postposition, but the forms are not cognate with each other. The Torau comitative postposition appears to be cognate with a comitative preposition found in NWS outside Mono-Uruavan. This points to a shift from preposed to postposed structure of an adpositional form, and requires further and more detailed historical research in order to understand more fully the processes of change. In the case of Uruava and Mono, we have, at present, found no evidence that these different forms have cognates in other Northwest Solomonic languages or are lexical copies from South Bougainville languages. The distinct ablative adpositions in Mono-Uruavan languages represent an innovative semantic category, but they display both original Oceanic prepositional structure (Mono and Torau) and innovative postpositional structure (Uruava, Torau). The origins of the forms of Mono-Uruavan ablative adpositions are not entirely clear. As mentioned

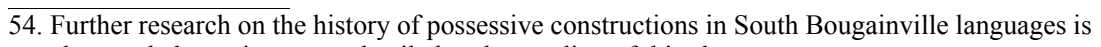
also needed to gain a more detailed understanding of this change.

55. The origins of Uruava - $g i$ 'plural possessum' and Torau $-n a$ 'singular possessum' are not entirely clear. It is possible that Torau $-n a$ represents the extension in function of $-n a$ '3SG.PSSR' influenced by its resemblance to Nasioi $a$ 'singular possessum'. Uruava -gi resembles the Buin plural suffix - $k i$ that occurs with kin terms and other animates (Laycock 2003). However, without more detailed investigation of the history of these possessive constructions and contact-induced formal changes in the Mono-Uruavan languages, these analyses remain speculative.

56. Note that this also represents a shift away from a typologically unusual system to one that occurs more frequently cross-linguistically (see Pantcheva 2010). It is possible that the semantic reorganization of adpositional categories in Mono-Uruavan languages represents an internally-motivated change, but we would argue that contact with South Bougainville languages was likely to have been at least one of the motivating factors.

57. Proto-Oceanic *i-ai 'there; oblique proform' has independently become a locative postposition in a number of other Oceanic languages that have developed postpositions as a result of linguistic contact with Papuan languages. See, for example, the locative postpositions in many Papuan Tip languages and in Kabana, Lusi, and Kove, three North New Guinea languages of New Britain (Ross 1988:208-9, 1996:194-95, Thurston 1987, Lynch, Ross, and Crowley 2002:104, Dunn and Reesink forthcoming). 
in 2.2, in other Northwest Solomonic languages an oblique with the role of source tends to be marked by a general locative preposition, while the source meaning is indicated elsewhere in the clause. In Banoni, the verb tsiganna 'to come from' has this function, occurring either alone or following other verbs (see Lincoln 1976a: $\$ 7.3,2005$ ). The resemblance of Mono tiga 'source' to the Banoni verb tsiganna 'to come from' (Lincoln 2005) is tantalizing, but they remain speculative cognates awaiting further comparative support. The distinction in distance between Torau aga 'source (near)' and iga 'source (distant)' would suggest a demonstrative origin (Malcolm Ross, pers. comm.), but at this stage we have not found likely cognate forms in other NWS languages or possible sources of lexical copying in the South Bougainville languages. Torau iga may be cognate with Mono tiga, although the apparent loss of *t in Torau would be irregular (see sound correspondences in Ross 1988:219).

Thus the Mono-Uruavan adpositions also suggest a history of interrelated changes, some of which are likely to have occurred before the break-up of their ancestral speech community, and others that have occurred independently in the three separate speech communities. Of note is that the semantic organization (location/goal versus source) and the structure (postnominal) show influence from South Bougainville languages, but none of the Mono-Uruavan languages have adpositional forms that are copies of South Bougainville forms (see tables 2 and 3 ).

Also important is the relationship between the different changes themselves. Three of the changes described here - the development of (i) SOV clause order, (ii) postpositions, and (iii) PSSR + SSM order in possessive constructions - involve a shift away from typically Oceanic left-headed structures to right-headed ones. The use of postpositions rather than prepositions and PSSR + PSSM order rather than the reverse are two features that Dryer (2007) shows correlate with the presence of OV order cross-linguistically. This raises the question as to whether these changes, motivated by contact with speakers of Papuan South Bougainville languages, also influenced each other. That is, the shift towards one right-headed structure may have further facilitated other shifts. The outcomes of these three changes in Mono-Uruavan languages are a general typological reorganization of the languages, as highlighted in table 6 by the structural differences between Mono-Uruavan languages and their sister Northwest Solomonic languages, and typological reorganizations that have continued in parallel to varying degrees of completion, as evidenced by that mix of prepositional, postpositional, and variable oblique marking. That this kind of contact-induced change tends to affect the structure of a language on a broad scale is predicted by some models of language contact (see Ross 2003b).

3.2 "STRUCTURAL" CONTACT-INDUCED CHANGE. All contact-induced changes described here for Mono-Uruavan are "structural" changes, that is, changes that have affected semantic and/or grammatical structure, but without the copying of phonological forms. Similar kinds of contact-induced change are widely discussed in the literature (for example, Gumperz and Wilson 1971, Thurston 1982, Soper 1996, Ross 1996, 2008, Aikhenvald 2002). Indeed, even the linguistic features that have changed in Mono-Uruavan languages - that is clause order, the expression of oblique arguments, and the order of partic- 
ipants in possessive constructions - are akin to contact-induced structural changes in other language contact situations.

This is particularly striking when the changes in Mono-Uruavan are compared with those found in other studies of contact-induced change in Oceania, namely Lusi of West New Britain (Thurston 1982) and Takia of Karkar island (Ross 1996, 2008). Both are also Oceanic languages spoken in Papua New Guinea that have undergone contactinduced change under the influence of neighboring Papuan languages. Some of the changes that have occurred in Takia and Lusi are summarized in table 7. As that table shows, in a similar way to Mono-Uruavan languages, Takia has developed SOV clause order and postpositions, and the semantic categories of the postpositions have been reorganized. Ross $(1996,2008)$ demonstrates that each of these characteristics of Takia represent innovations that were motivated by contact between Takia speakers and speakers of a neighboring Papuan language, probably Waskia. The changes in Lusi have affected different aspects of linguistic structure, but have led to similar kinds of outcomes. Thus in Lusi, a new set of postverbal modal particles has developed. These match the structure of the neighboring Papuan language, Anêm, and are different from the preverbal modal particles typical of Oceanic languages. The innovative modal particles also match the Anêm system of modals in terms of semantic organization (Thurston 1982). Takia also displays structural contact-induced change in the lexicon, with the semantic organization of words, compounds, and lexical collocations also showing parallels to those of Waskia (Ross 1996, 2008). Thurston describes similar parallels of semantic structure between Lusi and Anêm. However, unlike in Takia, in Lusi there has also been considerable lexical copying, with many lexical items, both in form and in meaning, being of Anêm origin (Thurston 1982). Further research is needed to determine more precisely the kinds of lexical changes that have affected the Mono-Uruavan languages.

This difference between contact-induced changes that result in the copying of structures and those that result in the copying of forms is a significant distinction in most models of language contact (for example, Thomason and Kaufmann 1988, Johanson 1999, Aikhenvald 2006, Matras and Sakel 2007). Ross (2007), however, presents a more finegrained categorization of structural contact-induced change, proposing three distinct types of change: lexical calquing, grammatical calquing, and metatypy. ${ }^{58}$ Ross (2007:124) defines metatypy as "the diachronic process whereby the morphosyntactic constructions of one of the languages of a bilingual speech community are restructured on the model of constructions of the speakers' other language, such that constructions of the replica language come to more closely match those of the model language in both meaning and morphosyntax." That is, metatypic changes are ones that affect the syntagmatic structure or word order patterns of a language, like the development of SOV clause order, postpositions, and prenominal possessors in Mono-Uruavan languages. Ross contrasts these kinds of changes with lexical and grammatical calquing, which are "the reorganisation of semantic patterns and ways of speaking" (Ross 2007:126) for lexical and grammatical patterns, respectively. Such changes affect paradigmatic patterns within a language, such as the semantic divisions within particular lexical domains or grammati-

58. We are employing Ross's (2007) refined definition of metatypy. This is a narrower definition than in some of Ross's earlier papers (for example, Ross 1996), in which metatypy and grammatical calquing were not so clearly distinguished. 
cal categories. Thus the reorganization of adpositions in Mono-Uruavan languages so as to distinguish source participants from locations and goals can be classified as grammatical calques. Table 7 categorizes the contact-induced changes of Mono-Uruavan, Takia, and Lusi in terms of Ross's (2007) distinctions.

While noting that the boundaries between these processes of change are fuzzy, Ross (2007) presents a number of case studies of languages that have undergone all three processes of change (for example, Takia) and languages that have undergone only lexical and grammatical calquing (for example, Mixe Basque). This patterning of these changes cross-linguistically leads Ross (2007) to propose that, chronologically, grammatical calquing does and must precede metatypy, although metatypy does not necessarily follow from grammatical calquing.

Ross's (2007) categorization and chronological ordering of contact-induced structural change is helpful in beginning to gain a greater understanding of the mechanisms of change that have led to the contemporary Mono-Uruavan languages. Distinguishing between grammatical calquing and metatypy highlights the presence of two processes of change in the development of the synchronic Mono-Uruavan expression of obliques. Grammatical calquing has resulted in the semantic reorganization of the system of adpositions (source versus location/goal), while metatypy has resulted in the shift from prepositional to postpositional expression of those semantic categories. Viewing these as two processes of change helps account for the variation found in Mono-Uruavan languages, where all three languages have developed the South Bougainville semantic organization, but in each language there are forms that are prepositions and forms that are postpositions, and in Torau and Uruava some forms can be prepositional or postpositional. This pattern of variation supports the chronology proposed by Ross (2007). That is, in Mono, the innovative ablative adposition tiga is prepositional, so it appears that the semantic reorganization may have preceded the development of postpositions, a change that is not complete in any of the three Mono-Uruavan languages. ${ }^{59}$ As also described in 3.2, these overlapping patterns of shared and independent contact-induced changes in Mono-Uruavan languages imply a complex history of development, andraise questions that can only be

\section{TABLE 7. STRUCTURAL CONTACT-INDUCED CHANGE IN TAKIA, LUSI, AND MONO-URUAVAN}

\begin{tabular}{|c|c|c|c|}
\hline $\begin{array}{l}\text { Takia } \\
\text { (Ross 1996, 2008) }\end{array}$ & $\begin{array}{l}\text { Lexical calquing } \\
\text { semantic reorganization of } \\
\text { words, compounds, lexical } \\
\text { collocations }\end{array}$ & $\begin{array}{l}\text { Grammatical calquing } \\
\text { semantic reorganization } \\
\text { of adposition categories }\end{array}$ & $\begin{array}{l}\text { Metatypy } \\
\text { SOV } \\
\text { V + TAM marker } \\
\text { N + postposition } \\
\text { N + determiner }\end{array}$ \\
\hline $\begin{array}{l}\text { Lusi } \\
\text { (Thurston 1982) }\end{array}$ & $\begin{array}{l}\text { semantic reorganization of } \\
\text { words, compounds, lexical } \\
\text { collocations (lexical copying) }\end{array}$ & $\begin{array}{l}\text { semantic organization of } \\
\text { modal categories }\end{array}$ & $\begin{array}{l}\mathrm{V}+\text { reciprocal } \\
\mathrm{V}+\text { modal particle }\end{array}$ \\
\hline $\begin{array}{l}\text { Mono-Uruavan } \\
\text { languages }\end{array}$ & $?$ & $\begin{array}{l}\text { semantic reorganization } \\
\text { of adposition categories }\end{array}$ & $\begin{array}{l}\text { SOV } \\
\mathrm{N}+\text { postposition } \\
\text { PSSR + PSSM } \\
\text { adposition stacking }\end{array}$ \\
\hline
\end{tabular}


answered with more detailed historical-comparative research on Mono-Uruavan languages in particular, and NWS languages more broadly. Ross's (2007) chronology would also predict that Mono-Uruavan languages have undergone some degree of lexical calquing. However, this and the issue of lexical copying between Mono-Uruavan and South Bougainville languages require further research.

4. CONCLUDING REMARKS. The detailed data presented in this paper on clause order, the expression of oblique arguments and adjuncts, and possessive constructions in Mono-Uruavan and South Bougainville languages illustrate the presence of structural innovations in Mono-Uruavan languages that have been influenced by the neighboring Papuan languages. The patterning of resemblant structures across all or some of the languages, particularly the changes to possessive constructions in Torau and Uruava that resemble structures found only in Nasioi and Nagovisi, raise questions regarding the relative chronology of certain changes and the nature of smaller areas of linguistic and social contact within the region as a whole.

The types of contact-induced change described for Mono-Uruavan have been associated in the literature with the sociolinguistic context of long-term bilingualism among speakers of different languages, and raise the question of whether this sociolinguistic context can also be reconstructed for the southern Bougainville region. They also raise the question of why Mono-Uruavan languages have undergone such significant contactinduced change, while other Northwest Solomonic languages, spoken alongside Papuan languages, have not. For example, Roviana and Ughele, two languages of New Georgia (Solomon Islands) with their neighboring Papuan language Touo (Baniata), and Piva and Banoni, two languages spoken on the west coast of Bougainville adjacent to South and North Bougainville Papuan languages, do not display the kinds of "Papuan-like" structures found in Mono-Uruavan languages. Lincoln (1976b) suggests that the lack of contact-induced language change in Banoni may be a result of "dual-lingualism," that is, a social setting in which speakers understand, but rarely speak, their neighbors' languages. He comments on Banoni and Motuna (under the name Siwai) speakers who understand each other's language, but typically address each other in their own languages (1976b:99), and he suggests that if Motuna speakers had used Banoni it may have led to the introduction of Motuna-like structures into the language. Social factors and the role of second-language learners are still recognized in the language contact literature as determining the presence and results of contact-induced language change. A more detailed analysis of past and present social settings in southern Bougainville is needed in order to gain a greater understanding of the contact-induced changes described in this paper.

Thus while the linguistic evidence presented here supports hypotheses in the anthropological and archaeological literature suggesting a sphere of social and cultural contact in the southern Bougainville and Shortland Islands region (see Thurnwald 1912a, 1912b, Terrell and Irwin 1972, Irwin 1973, Terrell 1978, Spriggs 1992), it is clear that even more detailed reconstruction of the linguistic history of this region promises to be fruitful for our understanding of the region's prehistory, as well as of contact-induced change more generally. 


\section{REFERENCES}

Aikhenvald, Alexandra Y. 2002. Language contact in Amazonia. Oxford: Oxford University Press.

- 2006. Grammars in contact: A cross-linguistic perspective. In Grammars in contact: A cross-linguistic typology, ed. by Alexandra Y. Aikhenvald and R. M. W. Dixon, 1-66. Oxford: Oxford University Press.

Allen, Jerry, and Conrad Hurd. 1963. Uruava word list. Unpublished MS. Ukarumpa, Papua New Guinea: Summer Institute of Linguistics.

Blust, Robert. 2000. Why lexicostatistics doesn't work: The "universal constant" hypothesis and Austronesian languages. In Time depth in historical linguistics, ed. by Colin Renfrew, April McMahon, and Larry Trask, 311-31. Cambridge: The McDonald Institute for Archaeological Research.

Boch, A. n.d. Short Alu grammar. Typescript.

Chafe, Wallace L. 1976. Givenness, contrastiveness, definiteness, subjects, topics and points of view. In Subject and topic, ed. by Charles N. Li, 25-55. New York: Academic Press.

Chambers, Mary. 2009. Which way is up? Motion verbs and paths of motion in Kubokota, an Austronesian language of the Solomon Islands. PhD thesis, School of Oriental and African Studies, University of London.

Davis, Karen. 2003. A grammar of the Hoava language, Western Solomons. Canberra: Pacific Linguistics.

Decker, Margaret. 1981. Notes on Nagovis grammar. Unpublished MS. Ukarumpa, Papua New Guinea: Summer Institute of Linguistics.

Dryer, Matthew S. 2007. Word order. In Language typology and syntactic description, ed. by Timothy Shopen, 61-131. Cambridge: Cambridge University Press.

Dunn, Michael. 2009. Contact and phylogeny in Island Melanesia. Lingua 119(11): 664-78.

Dunn, Michael, Stephen C. Levinson, Eva Lindström, Ger Reesink, and Angela Terrill. 2008. Structural phylogeny in historical linguistics: Methodological explorations applied in Island Melanesia. Language 84(4):710-59.

Dunn, Michael, and Ger Reesink. forthcoming. Austronesian-Papuan contact. In The languages and linguistics of the Pacific Islands: A comprehensice guide, ed. by Bill Palmer. Berlin: Mouton de Gruyter.

Durie, Mark. 1988. Verb serialization and "verbal-prepositions" in Oceanic languages. Oceanic Linguistics 27:1-23.

Evans, Bethwyn. 2009. Beyond pronouns: Further evidence for South Bougainville. In Discovering history through language: Papers in honour of Malcolm Ross, ed. by Bethwyn Evans, 73-101. Canberra: Pacific Linguistics.

Fagan, Joel L. 1986. A grammatical analysis of Mono-Alu (Bougainville Straits, Solomon Islands). Canberra: Pacific Linguistics.

Friedlaender, Jonathan S., François R. Friedlaender, Jason A. Hodgson, Matthew Stoltz, George Koki, Gisele Horvat, Sergey Zhadanov, Theodore G. Schurr, and D. Andrew Merriwether. 2007. Melanesian mtDNA complexity. PLoS One 2(2):e284.

Friedlaender, Jonathan S., François R. Friedlaender, Floyd A. Reed, Kenneth K. Kidd, Judith R. Kidd, Geoffrey K. Chambers, Rodney A. Lea, Jun-Hun Loo, George Koki, Jason A. Hodgson, D. Andrew Merriwether, and James L. Weber. 2008. The genetic structure of Pacific Islanders. PLoS Genet 4(1):e19.

Grace, George W. 1981. An essay on language. Columbia, SC: Hornbeam. . 1992. How do languages change? (More on "aberrant" languages). Oceanic Linguistics 31:115-30. 
1996. Regularity of change in what? In The comparative method reviewed: Regularity and irregularity in language change, ed. by Mark Durie and Malcolm Ross, 157-79. New York: Oxford University Press.

Griffin, Margie. 1974. Notes on the Buin language. Unpublished MS. Ukarumpa, Papua New Guinea: Summer Institute of Linguistics.

Gumperz, John J., and Robert Wilson. 1971. Convergence and creolization: A case from the Indo-Aryan/Dravidian border. In Pidiginization and creolization of languages, ed. by Dell Hymes, 151-68. Cambridge: Cambridge University Press.

Harrison, S. P. 2003. On the limits of the comparative method. In The handbook of historical linguistics, ed. by Brian D. Joseph and Richard D. Janda, 213-43 Oxford: Blackwells.

Hunley, Keith, Michael Dunn, Eva Lindström, Ger Reesink, Angela Terrill, Meghan E. Healy, George Koki, François R. Friedlaender, and Jonathan S. Friedlaender. 2008. Genetic and linguistic coevolution in northern Island Melanesia. PloS Genetics 4(10):e1000239.

Hurd, Conrad. 1977. Nasioi projectives. Oceanic Linguistics 16:111-78.

Hurd, Conrad, and Phyllis Hurd. 1970. Nasioi verbs. Oceanic Linguistics 9:37-78.

Irwin, G. J. 1973. Man-land relationships in Melanesia: An investigation of prehistoric settlement in the islands of the Bougainivlle Strait. Archaeology and Physical Anthropology in Oceania 8:226-52.

Johanson, Lars. 1999. The dynamics of code-copying in language encounters. In Language encounters across time and space, ed. by Bernt Brendemoen, Elizabeth Lanza, and Else Ryen, 37-62. Oslo: Novus.

Keil, Jared. 2005. Buin social structure. In Bougainville before the conflict, ed. by Anthony J. Regan and Helga M. Griffin, 332-45. Canberra: Panadanus Books.

Laracy, Hugh M. 1969. The Torau speakers of Bougainville-an historical note. Oceania 39(3):234-35.

Laycock, Donald C. n.d. Reflections on Buin transitivity. Unpublished MS. Canberra: Research School of Pacific Studies, Australian National University.

Laycock, Donald C. (ed. by Masayuki Onishi). 2003. A dictionary of Buin: A language of Bougainville. Canberra: Pacific Linguistics.

Lichtenberk, Frantisek. 1983. Relational classifiers. Lingua 60:147-76

1985. Possessive constructions in Oceanic languages and Proto Oceanic. In Austronesian Linguistics at the 15th Pacific Science Congress, ed. by Andrew Pawley and Lois Carrington, 93-140. Canberra: Pacific Linguistics.

2009. Oceanic possessive classifiers. Oceanic Linguistics 48:379-402.

Lincoln, Peter. 1976a. Describing Banoni: An Austronesian language of southwest Bougainville. PhD diss., University of Hawai'i.

.1976b. Banoni, Piva, and Papuanization. In Papers in New Guinea Linguistics, No. 19. Canberra: Pacific Linguistics, 77-105.

. 2005. Banoni dictionary. Unpublished MS. Honolulu: University of Hawai'i.

Lynch, John. 1981. Melanesian diversity and Polynesian homogeneity: The other side of the coin. Oceanic Linguistics 20:95-129.

Lynch, John, and Malcolm Ross. 2002. Banoni. In The Oceanic languages, ed. by John Lynch, Malcolm Ross, and Terry Crowley, 440-55. Richmond: Curzon Press.

Lynch, John, Malcolm Ross, and Terry Crowley, eds. 2002. The Oceanic languages. Richmond: Curzon Press.

Matras, Yaron, and Jeanette Sakel. 2007. Investigating the mechanisms of pattern replication in language convergence. Studies in Language 31(4):829-65.

Mosel, Ulrike, and Yvonne Thiesen. 2007. The Teop sketch grammar. Kiel: University of Kiel. [http://www.linguistik.uni-kiel.de/Teop_Sketch_Grammar_May07.pdf; accessed November 12, 2010, and September 5, 2011.] 
Ogan, Eugene. 2005. An introduction to Bougainville cultures. In Bougainville before the conflict, ed. by Anthony J. Regan and Helga M. Griffin, 47-56. Canberra: Panadanus Books.

Oliver, Douglas. 1938-39. Word lists of Bougainville languages. Unpublished MS. Cambridge MA: Harvard University.

Onishi, Masayuki. 1994. A grammar of Motuna (Bougainville, Papua New Guinea). $\mathrm{PhD}$ thesis, Australian National University.

Palmer, Bill. 2008. Passive possession in Oceanic. Studies in Philippine Languages and Cultures 18:119-41.

. 2009a. Clause order and information structure in Cheke Holo. Oceanic Linguistics 48:213-49.

- 2009b. Kokota grammar. Honolulu: University of Hawai'i Press.

Palmer, Bill, and Dunstan Brown. 2007. Heads in Oceanic indirect possession. Oceanic Linguistics 46:154-64.

Pantcheva, Marina. 2010. The syntactic structure of locations, goals and sources. Linguistics 48(5):1043-81.

Pawley, Andrew. 1973. Some problems in Proto-Oceanic grammar. Oceanic Linguistics 12:103-88.

. 2006. Explaining the aberrant Austronesian languages of southeast Melanesia: 150 years of debate. Journal of the Polynesian Society 115:215-58.

- 2009. The role of the Solomon Islands in the first settlement of Remote Oceania: Bringing linguistic evidence to an archaeological debate. In Austronesian historical linguistics and culture history: A festschrift for Robert Blust, ed. by Alexander Adelaar and Andrew Pawley, 515-40. Canberra: Pacific Linguistics.

Rankin, Robert L. 2003. The comparative method. In The handbook of historical linguistics, ed. by Brian D. Joseph and Richard D. Janda, 183-212. Oxford: Blackwell.

Rausch, P. J. 1912. Die Sprache von Südost-Bougainville, Deutsche Salomonsinseln. Anthropos 7:105-34, 585-616, 964-94, 1056-57.

Ross, Malcolm. 1988. Proto Oceanic and the Austronesian languages of western Melanesia. Canberra: Pacific Linguistics.

. 1996. Contact-induced change and the comparative method: Cases from Papua New Guinea. In The comparative method reviewed: Regularity and irregularity in language change, ed. by Mark Durie and Malcolm Ross, 180-217. New York: Oxford University Press.

- 2002. Sisiqa. In The Oceanic languages, ed. by John Lynch, Malcolm Ross, and Terry Crowley, 456-66. Richmond: Curzon Press.

2003a. Talking about space: Terms of location and direction. In The lexicon of Proto Oceanic: The culture and environment of ancestral Oceanic society, vol. 2: The physical environment, ed. by Malcolm Ross, Andrew Pawley, and Meredith Osmond, 187-220. Canberra: Pacific Linguistics.

. 2003b. Diagnosing contact-induced change. In Motives for language change, ed. by Raymond Hickey, 174-98. Cambridge: Cambridge University Press.

. 2005. Pronouns as a preliminary diagnostic for grouping Papuan languages. In Papuan pasts: Cultural, linguistic and biological histories of Papuan-speaking peoples, ed. by Andrew Pawley, Robert Attenborough, Jack Golson, and Robin Hide, 15-65. Canberra: Pacific Linguistics.

- 2007. Calquing and metatypy. Journal of Language Contact Thema 1:116-43. . 2008. A history of metatypy in the Bel languages. Journal of Language Contact Thema 2:149-64.

2010. Lexical history in the Northwest Solomonic languages: Evidence for two waves of Oceanic settlement in Bougainville and the northwest Solomons. In $A$ 
journey through Austronesian and Papuan linguistic and cultural space: Papers in honour of Andrew K. Pawley, ed. by John Bowden, Nikolaus P. Himmelmann, and Malcolm Ross, 245-70. Canberra: Pacific Linguistics.

Scheinfeldt, Laura B., François R. Friedlaender, Jonathan S. Friedlaender, Krista Latham, George Koki, Tatiana Karafet, Michael Hammer, and Joseph Lorenz. 2007. Y chromosome variation in northern Island Melanesia. In Genes, language and culture history in the southwest Pacific, ed. by Jonathan S. Friedlaender, 81-95. Oxford: Oxford University Press.

Silverstein, Michael. 1976. Hierarchy of features and ergativity. In Grammatical categories in Australian languages, ed. by R. M. W. Dixon, 112-71. Canberra: Australian Institute of Aboriginal Studies.

Soper, John. 1996. Loan syntax in Turkic and Iranian. Bloomington, Indiana: Eurolingua.

Spriggs, Matthew. 1992. Arachaeological and linguistic prehistory in the north Solomons. In The language game: Papers in memory of Donald C. Laycock, ed. by Tom Dutton, Malcolm Ross, and Darrell Tryon, 417-26. Canberra: Pacific Linguistics.

Terrell, John. 1978. Archaeology and the origins of social stratification in southern Bougainville. Publications de la Société des Océanistes 39:23-43.

Terrell, John Edward, and G. Irwin. 1972. History and tradition in the northern Solomons: An analytical study of the Torau migration to southern Bougainville in the 1860s. Journal of the Polynesian Society 81:317-49.

Thomason, Sarah Grey, and Terrence Kaufmann. 1988. Language contact, creolization, and genetic linguistics. Berkley: University of California Press.

Thurnwald, Richard C. 1912a. Forschungen auf den Salomo-Inseln und dem BismarckArchipel mit Unterstützung der Baessler Stuftung herausgegeben im Auftrage der General Verwalktung der Königlichen Museen zu Berlin. Vol. Band III: Volk, Staat und Wirtschaft. Berlin: Dietrich Reimer.

_. 1912b. Forschungen auf den Salomo-Inseln und dem Bismarck-Archipel mit Unterstützung der Baessler Stuftung herausgegeben im Auftrage der General Verwalktung der Königlichen Museen zu Berlin. Vol. Band I: Leider unde Sagen aus Buin. Berlin: Dietrich Reimer.

Thurston, William R. 1982. A comparative study in Anêm and Lusi. Canberra: Pacific Linguistics.

- 1987. Processes of change in the languages of north-western New Britain. Canberra: Pacific Linguistics.

- 1994. Renovation and innovation in the languages of north-western New Britain. In Language contact and change in the Austronesian world, ed. by Tom Dutton and Darrell T. Tryon, 573-609. Berlin: Mouton de Gruyter.

Wheeler, Gerald Camden. 1912. Mono. Le Maitre Phontique 1-2:12-14

_. 1926. Mono-Alu folklore (Bougainville Strait, Western Solomon Islands). London: George Routledge \& Sons.

White, Geoffery M., Francis Kokhonigita, and Hugo Pulomana. 1988. Cheke Holo (Maringe/Hograno) dictionary. Canberra: Pacific Linguistics. 